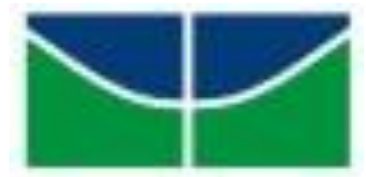

Universidade de Brasília - UnB

Instituto de Ciências Humanas - IH

Departamento de Serviço Social - SER

Tainá Luiza Timm Lopes

Análise dos Organismos de Execução e Implementação da Política de Assistência Social voltada para a População de Rua de Brasília

Brasília - DF

Setembro de 2010 
Tainá Luiza Timm Lopes

\section{Análise dos Organismos de Execução e Implementação da Política de Assistência Social voltada para a População de Rua de Brasília}

Trabalho de Conclusão de Curso (TCC) de graduação em Serviço Social apresentado ao Departamento de Serviço Social da Universidade de Brasília, como requisito parcial para a obtenção do título de Bacharel em Serviço Social.

Orientadora: Prof ${ }^{a}$. Ms. Camila Potyara Pereira

Brasília - DF

Setembro de 2010 
Tainá Luiza Timm Lopes

\title{
Análise dos Organismos de Execução e Implementação da Política de Assistência Social voltada para a População de Rua de Brasília
}

\author{
COMISSÃO EXAMINADORA
}

Prof ${ }^{a}$. Ms. CAMILA POTYARA PEREIRA

Orientadora

(Departamento de Serviço Social da Universidade de Brasília)

\begin{abstract}
Prof ${ }^{a}$. Dra. POTYARA A. PEREIRA
(Departamento de Serviço Social da Universidade de Brasília - SER/IH/UnB)

Prof ${ }^{a}$. Dra. MARIA SALETE KERN MACHADO

(Departamento de Sociologia da Universidade de Brasília - SOL/ICS/UnB)

Examinador Externo
\end{abstract}

Brasília, 09 de Setembro de 2010. 


\section{AGRADECIMENTOS}

Agradeço à minha querida família, em especial à minha mãe por todo apoio, paciência e incentivo durante a minha graduação na Universidade de Brasília.

Ao Marcos Vinícius, por ter me acompanhado e apoiado de maneira ímpar todos esses anos de universidade, pela paciência e carinho nos momentos mais difíceis.

À turma de Serviço Social e ao grupo PET/SER, que foram de fundamental importância para que a minha trajetória na UnB fosse tão especial.

À minha melhor amiga, Maria Cecília, companheira de todas as horas, e que principalmente durante o processo de monografia teve paciência em ler e reler diversas vezes minhas escritas, sempre de bom humor, pelo simples motivo de estar me ajudando.

À querida Nayara, que além de me dar muita força, me ensinou que as dificuldades podem ser superadas quando se tem fé e boa vontade no que se faz.

Aos professores e funcionários do departamento de Serviço Social, sem os quais, não seria possível esta trajetória repleta de aprendizagem.

E principalmente, à Professora Camila Potyara, que sempre esteve presente de forma atenciosa. Muito mais do que uma professora, você foi uma amiga, seu zelo e carinho fizeram toda a diferença durante essa caminhada. 


\section{RESUMO}

A presente pesquisa se propõe a analisar a relação e articulação entre os organismos responsáveis pela execução das políticas sociais voltadas para a população de rua no Distrito Federal, mais especificamente, a Secretaria de Estado de Desenvolvimento Social e Transferência de Renda (SEDEST), e a Subsecretaria de Defesa do Solo e da Água (SUDESA), ressaltando as dificuldades dos referidos órgãos em tornar o processo de acolhimento da população de rua mais eficaz e direcionado, no sentido da construção de políticas que realmente atendam às suas reais demandas. Para tanto, teve como objetivo geral mostrar que através de precária articulação, a Capital Federal não tem qualidade na efetivação das citadas políticas. A pesquisa foi realizada tendo como suporte teórico o método histórico-estrutural, visto que, nesta abordagem, a realidade é construída historicamente, influenciando e sendo influenciada pela sociedade. O método escolhido analisa a formação política, econômica e social das relações sociais, e aborda, de forma crítica, os objetos observados na realidade em estudo. As entrevistas foram realizadas com pessoas que ocupam cargos ou posições centrais nas instituições em alvo (SEDEST e SUDESA), além de pessoas que vivem nas ruas do Plano Piloto.

Palavras-chave: assistência social, pobreza, população de rua. 


\section{SUMÁRIO}

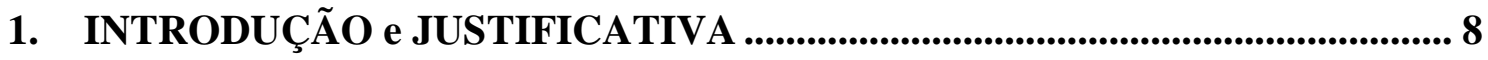

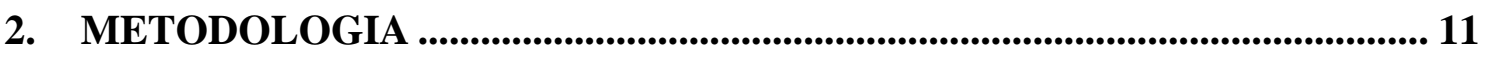

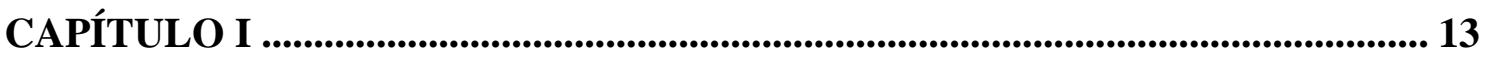

A ASSISTÊNCIA SOCIAL: DILEMAS E PERSPCTIVAS HISTÓRICAS........... 13

REGULAMENTAÇÃO DA ASSISTÊNCIA SOCIAL .................................................... 14

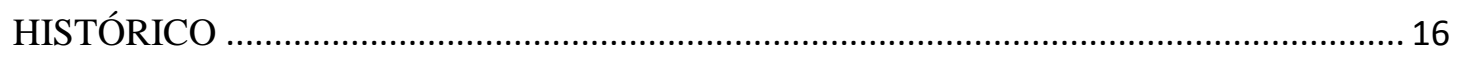

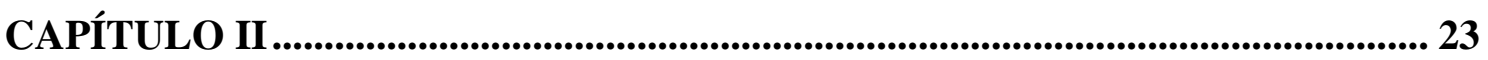

O Fenômeno da População de Rua ................................................................................................ 23

Histórico da População de Rua ......................................................................................... 25

A origem do fenômeno população de rua no Brasil ................................................................... 29

População de Rua do Distrito Federal ................................................................................... 32

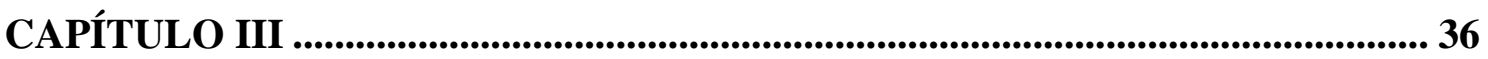

Correlação de Forças: Governo x População de rua................................................. 36

SUBSECRETARIA DE DEFESA DO SOLO E DA ÁGUA (SUDESA) ………................... 37

SECRETARIA DE ESTADO DE DESENVOLVIMENTO SOCIAL E TRANSFERÊNCIA

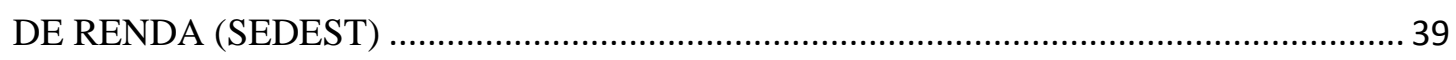

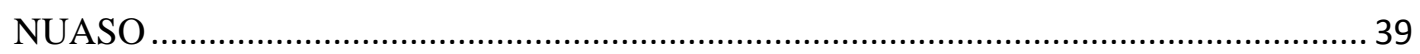

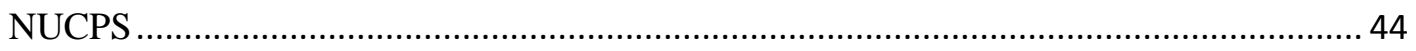

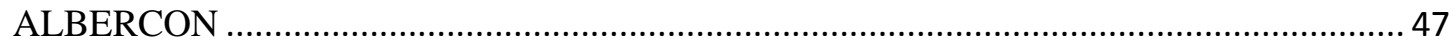

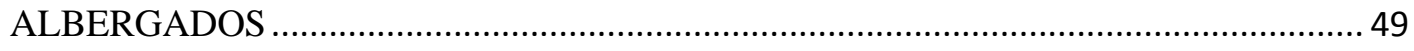

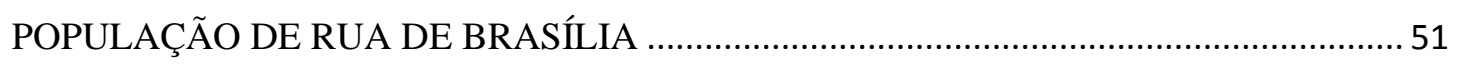

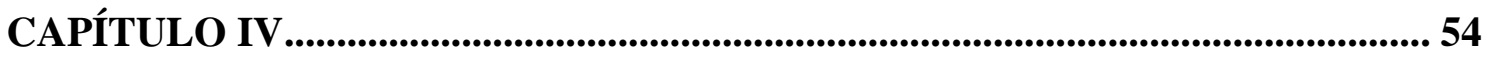

A relação entre a SUDESA e a SEDEST e suas implicações para a população de rua .............................................................................................................................................................. 54

O DESCONHECIMENTO DA REALIDADE DA POPULAÇÃO DE RUA ……................. 54

DESARTICULAÇÃO ENTRE SUDESA e SEDEST …..................................................... 56 
POLÍTICAS DE ASSISTÊNCIA SOCIAL PARA A POPULAÇÃO DE RUA 59 CONSIDERAÇÕES FINAIS. 62

REFERÊNCIAS BIBLIOGRÁFICAS 63 


\section{INTRODUÇÃO e JUSTIFICATIVA}

A presente pesquisa é resultado da disciplina Trabalho de Conclusão de Curso (TCC), sob orientação da professora Camila Potyara, oferecida durante o primeiro semestre de 2010.

Ao cursar as disciplinas de Seguridade Social 1 (1\%/2009) e Tópicos Especiais em Política Social - Pobreza Desigualdade e o Fenômeno População de Rua (2\%/2009), a aluna teve contato com a trajetória da Assistência Social e da Previdência Social no sistema capitalista, perpassando a análise da origem da pobreza, sua intensificação e persistência no capitalismo. O estudo da desigualdade social, tendo como uma de suas conseqüências o fenômeno da população de rua, instigou a aluna a iniciar uma reflexão de como são feitas e implementadas as políticas sociais para a população de rua na Capital do Brasil, mais especificamente no Plano Piloto do Distrito Federal.

As disciplinas citadas proporcionaram a leitura de autores como Potyara Pereira, Camila Potyara, Leo Huberman, Tocqueville, Lícia Valadares, entre outros, o que fomentou a discussão acerca da pobreza e da indigência no sistema capitalista, além de servirem como base para utilização e diferenciação de conceitos como os de pobreza absoluta, pobreza relativa, e população de rua.

A Pesquisa realizada se justifica por considerar que na área nobre da capital Plano Piloto, o Governo tem a tendência de omitir dados reais referentes à população de rua, passando uma idéia de que há um baixo nível de desigualdade no DF. A utilização de medidas paliativas - e muitas vezes, de caráter punitivo - para assistir os indivíduos em vulnerabilidade descaracteriza o Estado como provedor e garantidor de direitos aos cidadãos, e impõe ao mesmo um papel de reprodutor da pobreza. A partir disso, tem-se a necessidade de caracterizar o que é a população de rua e o que a caracteriza.

As condições em que se encontra a população de rua de Brasília apresentam algumas especificidades quando são feitas comparações com outros lugares. Grande parte desta população é formada por migrantes, que, à procura de melhores condições de vida, migram para a Capital. Essa população à margem da sociedade, ao contrário do que é noticiado, é formada em sua maioria por trabalhadores (catadores de lixo, flanelinhas, lavadores de carro), que moram em invasões irregulares, ou mesmo em áreas abandonadas do Plano Piloto. Na rua também é encontrado um grande número de 
famílias, e um número ainda maior de mulheres, o que, mais uma vez, distingue a formação da população de rua de Brasília em relação a outras cidades.

O foco desta Pesquisa é entender como se dá a realização do trabalho dos Organismos do Governo do Distrito Federal, encarregados pela execução de políticas assistenciais para a população de rua. Estes, que serão estudos no respectivo trabalho são: a Secretaria de Estado de Desenvolvimento Social e Transferência de Renda (SEDEST), e a Subsecretaria de Defesa do Solo e da Água (SUDESA).

A importância desta Pesquisa, além de sua atualidade, se deve à escassez de trabalhos publicados relacionados às condições de vida da população de rua de Brasília, principalmente no que se refere à qualidade das políticas assistenciais. A necessidade de entender o processo de "inclusão" da população de rua da capital se mostra fundamental para o favorecimento do desenvolvimento de políticas assistenciais mais eficazes.

Cabe ressaltar, que devido ao contexto de greve instaurado na Universidade de Brasília, durante o primeiro semestre de 2010, e além das próprias dificuldades decorrentes de um Trabalho de Conclusão de Curso - TCC, destaco que o presente trabalho apresenta limitações, que se justificam devido ao curto espaço de tempo para a realização do trabalho de campo, assim como também, para a análise de dados e construção do texto final.

Nesse contexto, sabe-se que o número de entrevistas foi restringido, e que a breve discussão de alguns temas impossibilitou discussões mais aprofundadas, que em outro momento poderão ser problematizadas com maior atenção.

\subsection{OBJETO / QUESTÃO DE PARTIDA / PROBLEMA}

Como visto na introdução desta Pesquisa, o fenômeno população de rua está presente em todas as grandes cidades brasileiras. No Distrito Federal, não é diferente. Em resposta a este fenômeno, os Governos estaduais e municipais têm adotado diferentes estratégias políticas que podem contribuir para o enfrentamento desta crítica questão e para proteção social dos indivíduos nela envolvidos. Na Capital Federal, existem duas instituições do Governo que desenvolvem, entre outras atividades, ações específicas para a população de rua: SEDEST e SUDESA. 
A primeira Secretaria visa à integração das políticas públicas de assistência social e segurança alimentar, através da promoção da inclusão social, e da efetivação do exercício da cidadania. A SEDEST é dividida em quatro Subsecretarias e uma Unidade Geral de Administração ${ }^{1}$, assim como também, possui sua estrutura dividida em diversos núcleos voltados para atendimentos específicos. O Núcleo Especializado de Abordagem Social em Espaços Públicos (NUASO) e o Núcleo de Proteção em Situação de Calamidades Públicas e de Emergências (NUCPS) representam, respectivamente, o ponto de partida de integração da população de rua, realizado através das abordagens que proporcionam encaminhamentos para diferentes lugares ou políticas, de acordo com a necessidade existente, e o trabalho de acolhimento e encaminhamento de pessoas em situação de risco, como por exemplo, durante uma ação de remoção. Juntamente com a SUDESA, o NUASO e o NUPCS comporão a unidade de análise privilegiada desta Pesquisa.

Tendo como base o que foi colocado, é importante ressaltar algumas indagações que originaram o interesse pela Pesquisa: existe articulação eficaz entre os organismos que atuam em parceria na efetivação das políticas sociais voltadas aos moradores de rua? Pode-se realmente afirmar que o Distrito Federal possui essas políticas? Até que ponto elas são simplesmente paliativas?

Após a discussão do problema e a exposição das questões de partida que orientarão esta Pesquisa, o objeto do presente trabalho é a relação e articulação entre a SUDESA e a SEDEST, responsáveis pela execução das políticas sociais voltadas para a população de rua no Distrito Federal, ressaltando as dificuldades dos referidos órgãos em tornar o processo de acolhimento desses indivíduos mais eficaz e direcionado, no sentido da construção de políticas que realmente atendam às suas reais demandas.

\subsection{OBJETIVO GERAL}

\footnotetext{
${ }^{1}$ Subsecretaria de Assistência Social (SUBSAS), Subsecretaria de Segurança Alimentar e Nutricional (SUBSAN) e Subsecretaria de Transferência de Renda (SUTRAR), Subsecretaria de Planejamento e Gestão (SUBPLAGI).
} 
Mostrar que através da precária articulação entre Organismos do Governo do DF que atuam em parceria na execução das políticas sociais voltadas aos moradores de rua, a Capital Federal não tem qualidade na efetivação das citadas políticas.

\subsubsection{OBJETIVOS ESPECÍFICOS}

1) Entender os limites na implementação das políticas sociais voltadas para a população de rua.

2) Verificar se a população de rua do Plano Piloto é assistida pelas políticas do Governo do Distrito Federal.

\subsection{HIPÓTESES}

1) Os organismos que executam as políticas sociais voltadas para a população de rua do Distrito Federal, não têm uma articulação eficaz, o que prejudica a continuidade e o acompanhamento das ações de forma que não se alcancem resultados positivos na implementação das referidas ações.

2) As políticas sociais do Governo do Distrito Federal para a população de rua podem ser consideradas ações paliativas, visto que o principal objetivo não é a melhoria da qualidade de vida dessas pessoas, mas, de certa forma, a efetivação de uma política de "higienização" na Capital Federal.

\section{METODOLOGIA}

\subsection{MÉTODO}

A pesquisa foi realizada tendo como suporte teórico o método históricoestrutural, visto que, nesta abordagem, a estrutura e a história mantêm uma relação dialética de influência mútua. Neste caso, a realidade da população de rua e os tipos de atendimentos ou ações sociais voltados a ela, são analisados mediante a constatação de que estes não são fenômenos e práticas naturais, mas construídos historicamente, influenciando e sendo influenciados na estrutura contraditória da política social e da sociedade. O método escolhido analisa a formação política, econômica e social das relações sociais, e aborda, de forma crítica, os objetos observados na realidade em estudo. 
O método histórico-estrutural ao possibilitar uma análise histórica sobre o fenômeno a ser estudado, subentende que o mesmo faz parte de uma construção, em que o fato se revela como uma produção e reprodução, e não como algo natural ou inerente à esfera social (Pereira, 2009).

Sendo assim, neste trabalho foi abarcado o surgimento, a intensificação, e o desenvolvimento da população de rua, partindo de um contexto geral que vai se delimitando até as particularidades deste fenômeno encontradas em âmbito nacional. A elucidação da constituição do fenômeno da população de rua no Brasil permite o encontro de especificidades no âmbito do Distrito Federal, que foi o local escolhido para analisar a efetividade das ações voltadas para pessoas que vivem na e da rua.

\subsection{PROCEDIMENTOS METODOLÓGICOS}

A técnica escolhida para a coleta de dados foi a de entrevistas semi-estruturadas, visto que, através destas, é possível interrogar os atores sociais sem restringir as perguntas a opiniões pré-estabelecidas e dar abertura para que o entrevistado conduza o diálogo sem fugir dos pontos investigados; abrir espaço para introduzir perguntas e fazer intervenções, ampliando assim, o nível de informações e opiniões extraídas; compreender e conhecer internamente os dilemas e questões enfrentados e, a partir disso, ter acesso às experiências dos indivíduos; e alcançar o ponto de vista dos atores sociais e de considerá-los para compreender e interpretar as suas realidades. Vale lembrar que a prática da entrevista pode ser usada como um meio de denúncia para os abusos que os sujeitos estudados podem estar sofrendo, independente de serem moradores de rua ou mesmo funcionários do Governo.

Desta forma, os procedimentos metodológicos desta Pesquisa abarcaram, além de entrevistas semi-estruturadas com gravação, pesquisa de dados em fontes secundárias, como sites e reportagens, e leitura bibliográfica especializada. Foram realizadas um total de 13 entrevistas, sendo que destas, 4 se deram com população de rua do Plano Piloto, 4 com albergados, 2 com o coordenador da SUDESA, 2 com pessoas que ocupavam cargo central na SEDEST, e 1 com a coordenadora do ALBERCON. Ressalta-se que a população de rua entrevistada residia próximo à Universidade de Brasília. 


\section{CAPÍtULO I}

\section{A ASSISTÊNCIA SOCIAL: DILEMAS E PERSPCTIVAS HISTÓRICAS}

A história da assistência social brasileira pode ser lida como a história de uma política em constante conflito com as formas capitalistas de organização social. Mesmo sem ter a pretensão de escrever essa história, é possível afirmar que a assistência social sempre se debateu para encontrar seu lugar e sua identidade ao lado da organização social do trabalho. Direito de cidadania, política compensatória ou caridade? Esses parecem ser alguns dos dilemas inerentes à política assistencial, a qual nunca abandonou o cenário social e sempre perpassou as outras políticas sociais, constituindo uma associação ao mesmo tempo complexa e paradoxal (BOSCHETTI, 2006, pag. v).

Neste capítulo será realizada uma breve análise a respeito da política de assistência social. A discussão abarcará, de forma geral, a história da assistência, o que essa política representa, e como ela é percebida pela sociedade. A dificuldade no entendimento do que vem a ser a política de assistência social, assim como qual é a sua função na sociedade, acarreta críticas pejorativas tanto para a própria política, quanto para seus beneficiários. A visão caritativa, impregnada na política de assistência, é considerada um exemplo dessa percepção.

A partir disso, destaca-se que o rótulo negativo, arraigado ao conceito de assistência social, ao mesmo tempo em que constrange, estigmatiza os destinatários de benefícios e serviços assistenciais, também, intimida o uso do termo "assistência social" na implementação de programas e projetos, sejam estes, governamentais ou não. Podese comprovar esse fato pela constante troca de denominações que a política recebe.

[...] onde ela [a assistência social] é necessária como parte integrante de políticas de proteção social concretizadoras de direitos, arranja-se logo uma outra denominação, com o intuito de transformar o processo assistencial, insubstituível de fato, em algo semanticamente nobre ou prestigiado nos "modernos" círculos intelectuais e políticos (PEREIRA, 1996, pag.11).

De acordo com Potyara Pereira (1996), é mais comum relacionar o conceito de assistência social à sua função do que ao seu conteúdo, fato que limita a política a "um raciocínio circular e teleológico, que nunca diz o que ela é, mas o que se propõe a ser." (pag.34) A autora argumenta que da mesma maneira como acontece em outros fenômenos, a assistência social não se limita a uma única função, característica que permite sua presença em diferentes conjunturas: no sistema capitalista, no socialismo, em democracias. 
Tal fato serve para desmistificar a visão da assistência social vinculada ao sustento da pobreza, pois, mais do que atender aos menos favorecidos, essa política visa à garantia de direitos, contribuindo para proporcionar melhores condições de vida aos sujeitos. Estes, não precisam necessariamente ser pobres, mas podem estar inseridos em contextos de vulnerabilidade social.

$\mathrm{O}$ contexto neoliberal ${ }^{2}$ tem como uma de suas principais características, a desarticulação dos direitos sociais, que se dá, em primeira instância, por meio da desresponsabilização do Estado quanto à garantia desses mesmos direitos, fato este que pode ser considerado um dos entraves à consolidação da assistência social como direito do cidadão. Concomitantemente a esse processo, há uma transferência da responsabilidade social para os diversos setores da sociedade civil, o que inclui os próprios indivíduos, que passam a ser culpabilizados por sua situação de miséria.

A relutância do Estado em aceitar a assistência social como um direito se deve, em parte, porque esta política não tem (diretamente) o trabalho como contrapartida para o recebimento de benefícios. Esse último ponto intensifica a visão que qualifica a assistência social como uma política que sustenta e reproduz a pobreza.

\section{REGULAMENTAÇÃO DA ASSISTÊNCIA SOCIAL}

A partir do desenvolvimento da acumulação primitiva ${ }^{3}$, tem-se a ampliação do exército industrial de reserva, o que dificultou a mobilização da classe trabalhadora, tendo em vista, que os indivíduos insatisfeitos com sua situação são facilmente inseridos em um mercado de trabalho precarizado, que, tendo o lucro como objetivo primordial acaba por explorar de forma intensa o proletariado. Esses acontecimentos geraram grande instabilidade no campo de trabalho, o que por sua vez, acarretou na disseminação do desemprego de longa duração, do trabalho precário, dos 'bicos', diminuindo, portanto, a qualidade de vida dos trabalhadores.

\footnotetext{
${ }^{2}$ De acordo com Antunes (1999), o modelo econômico neoliberal é uma espécie de resposta à crise estrutural que se deu em fins da década de 1970, com o objetivo claro de reproduzir a ordem do capital. Tal modelo se caracteriza, portanto, pela reestruturação produtiva; privatização acelerada; enxugamento do aparato estatal; políticas fiscais e monetárias sintonizadas com os organismos mundiais, tais como: o FMI e desmontagem dos direitos sociais; combate ao sindicalismo classista; dentre os principais fatores que configuraram o ideário neoliberal.
}

\footnotetext{
${ }^{3}$ A acumulação primitiva constitui a pré-história do capital e do modo de produção capitalista.
} 
Em decorrência desse processo, tem-se uma população que não encontra seu lugar na sociedade. Assim, a subalternidade é expressa em um amplo conjunto de perspectivas, características, ações, e interesses, que configuram um leque de desigualdades, injustiças e opressões, no qual a inserção na vida social tem a desigualdade como condição reiteradora.

Dentro desse contexto, e levando em conta "o reconhecimento das autoridades públicas de que a pobreza no capitalismo era produto do próprio desenvolvimento predatório desse sistema" (PEREIRA, 2000, pag.60), percebeu-se como necessário a proteção da classe trabalhadora pelo Estado que, através da intervenção social, passou a utilizar a política social para atender esses sujeitos. Ressalta-se que esta iniciativa teve como objetivo primordial proteger o próprio sistema capitalista, a partir do controle estratégico das massas por parte do Estado.

Sendo assim, a assistência social foi instituída como política pública após a Segunda Guerra Mundial por meio do desenvolvimento da seguridade social. Anterior a este fato,

[...] existiam escassas atenções públicas às necessidades sociais, geridas por um Estado ainda socialmente restrito. Exemplos clássicos dessas atenções - que viam no pobre não um titular de direitos, mas um perigo à ordem pública - são as Leis dos Pobres inglesas (Poor Laws) (PEREIRA, 2000, pág.61)

Essas legislações podem ser entendidas como o início da assistência social institucional. No próximo capítulo este tema será discutido mais detalhadamente, mas cabe esclarecer, que a assistência social surge com a implementação de regulamentações contra a perambulância de pessoas que vagavam pelas cidades - devido ao contexto de desapropriação de terra dos camponeses, e a não absorção dessa mão de obra pelo capital. Nesse contexto criaram-se as chamadas workhouses, nas quais, os indivíduos que fossem recolhidos nas ruas deveriam trabalhar em troca de acolhimento. Acrescenta-se que dentro dessa conjuntura a assistência social funcionava

[...] simultaneamente, como controle sobre o trabalho e sobre possíveis consequiências negativas, para a ordem prevalecente, de uma pobreza não confinada territorialmente. Sua índole era mais punitiva que protetora, mas não muito eficiente e eficaz no alcance de seus objetivos (PEREIRA, 2000, pág.62).

Por estar inserida em um contexto marcado por contradições de classes, a assistência social deve ser entendida como um fenômeno contraditório, tendo em vista 
que "é produto e expressão objetivada de conflitos de interesses, exigindo do Estado e da sociedade a participação". (PEREIRA, 1989, pág.50) A partir do momento em que a assistência social tem como uma de suas características, responder a quem possui maior domínio, depreende-se a necessidade de que tanto os profissionais de serviço social, quanto a própria sociedade, sejam capazes de se mobilizar e lutar para que as conquistas sociais sejam realmente efetivadas.

Destarte, por ser regida por meio da disponibilidade, ou não, de recursos governamentais, a política de assistência social, é utilizada de maneira paliativa e pontual, o que deve ser considerado como um problema, visto que, tal fato não garante a continuidade do atendimento à população em situação de vulnerabilidade, e ao primeiro sinal de crise, a verba para as ações da política são cortadas.

É importante refletir que sempre existiram e sempre existirão pessoas com necessidades sociais, e por isso, a política de assistência social se faz tão necessária. $O$ Estado tem que reconhecer a dívida social que possui com a população em situação de vulnerabilidade, pois caso essa população credora não seja assistida, permanecerá no ciclo vicioso da pobreza que ainda se faz presente na atualidade.

Nesse sentido observa-se que há necessidade de politizar dentro da própria sociedade, o que vem a ser de fato a política de assistência social, pois ao democratizar seu entendimento, abre-se a possibilidade dos sujeitos reivindicarem seus direitos e usufruírem os que já foram conquistados.

\section{HISTÓRICO}

A intensificação da pobreza por meio do modelo de produção capitalista tem como conseqüência a necessidade de intervenção estatal por meio de ações que atendam demandas relativas às necessidades humanas, sejam elas sociais ou históricas. (PEREIRA, 1996) A urgência na melhoria das condições de vida dos trabalhadores ocasionou a formulação de sistemas de seguridade social que visavam à instituição de direitos e proteção aos trabalhadores, em que o Estado é tido como garantidor dos mesmos.

[...] o reconhecimento das autoridades públicas de que a pobreza no capitalismo era produto do próprio desenvolvimento predatório desse sistema que, para ser preservado, exigia que o Estado protegesse o trabalhador contra a perda de renda advinda de 
doenças, acidentes, envelhecimento, mortes prematuras, dentre outras contingências sociais (PEREIRA, 2000, pág.60).

Nesse sentido, é importante expor, de maneira sucinta, o desenvolvimento das práticas estatais intervencionistas, nas quais se desenvolveu o Welfare State ${ }^{4}$, ou, em outras palavras, o Estado de bem-estar social ${ }^{5}$.

No final do século XIX, com a crescente organização política das classes trabalhadoras, iniciou-se na Alemanha a ampliação de benefícios previdenciários em respostas às greves e pressões dos operários. Tem-se a partir disso, a instauração do modelo bismarckiano de seguridade social, o qual se orienta pela "lógica do mérito individual, caracterizado por contribuição individual como critério para o aferimento de benefícios, valendo também para a aposentadoria" (ZIMMERMANN, 2008). Destacase que esse sistema deixa à margem significativa parcela da população, que por não estar inserida no mercado de trabalho, não possui condições de contribuir para a previdência social.

Durante a Segunda Guerra Mundial, implantou-se na Inglaterra o Plano Beveridge. Este deve ser entendido como um modelo mais avançado de seguridade social, visto que, ao propor uma nova lógica de proteção social, apresentava a universalidade dos direitos sociais como uma de suas principais características. Nesse sistema, cabe ao Estado a manutenção dos gastos destinados à proteção social dos cidadãos através do recolhimento de tributos/impostos de maneira geral.

"O Sistema de Seguridade Social de Beveridge inovou, de fato, por ser nacional e unificado e conter um eixo distributivo, ao lado do contributivo, além de abolir os testes de meio no âmbito da assistência social" (PEREIRA, 2000, pag.93). Contudo, faz-se necessário esclarecer que tal modelo também apresentou pontos falhos como, por exemplo, o fato de ser baseado em recolhimento de impostos regressivos ${ }^{6}$, o que se mostrou inviável, tendo em vista o déficit gerado nas finanças do Estado e do pouco alcance das políticas à população necessitada.

\footnotetext{
${ }^{4} \mathrm{O}$ "Welfare State que, para muitos, começou a ser formado na Europa, no último terço do século XIX, se firmou em meados do século XX como a instituição diretamente responsável pelo atendimento de necessidades sociais agravadas pelo inexorável desenvolvimento capitalista.” (PEREIRA, 2000, pag.59)

${ }^{5}$ Surge, "após o término da II grande conflagração mundial a formação dos Estados do Bem-Estar Social, ao menos até o início da década de 1970, mobilizando grande parte das estruturas dos Estados para uma frente intervencionista, adaptando-se às novas exigências políticas e sociais, nas quais os direitos sociais ganharam muito mais relevo." (JUNIOR, 2004)

${ }^{6}$ Nos impostos de caráter regressivo os contribuintes de maior poder aquisitivo pagam uma fração menor de sua renda do que os contribuintes menos afortunados.
} 
Devido a diferenças históricas e políticas entre os diversos países, a efetivação dos sistemas beveridgiano e bismarckiano ocorreu de forma heterogênea. No caso brasileiro, os princípios do sistema bismarckiano predominam na previdência social, e os do modelo beveridgiano orientam o atual sistema público de saúde (com exceção do auxílio doença, tido como seguro saúde e regido pelas regras da previdência) e de assistência social, o que faz com que a seguridade social brasileira se situe entre o seguro e a assistência social (BOSCHETTI, 2006).

Cabe elucidar que somente com a Constituição Federal de 1988 que a regulamentação da política de assistência social passou a adquirir caráter legal.

Efetivamente, embora desde 1934 as Constituições Federais venham disciplinando direitos e relações de trabalho, como forma de regular a economia e o mercado, só em 1988 os destituídos, inclusive de condições de trabalho, foram legalmente amparados no seu direito de proteção gratuita e desmercadorizável pelos poderes públicos. A partir de então, a assistência social deixa de ser, pelo menos em tese, uma alternativa ou expectativa de direito e se transforma em direito formal, da mesma forma que os destinatários dessa assistência deixam de ser meros clientes da proteção social do Estado e da sociedade e se transformam em cidadãos detentores do direito a uma proteção pública devida, nos termos da lei (PEREIRA, 1996, pag.66).

A conceituação de assistência social deste trabalho teve como base os artigos 203 e 204 da Constituição Federal (CF) de 1988, e as definições presentes na Lei Orgânica de Assistência Social (LOAS), instituída em dezembro de 1993. A política de assistência social é

direito do cidadão e dever do Estado, é Política de Seguridade Social não contributiva, que provê os mínimos sociais, realizada através de um conjunto integrado de ações de iniciativa pública e da sociedade, para garantir o atendimento às necessidades básicas. (LOAS, Art.1, 1993).

Com fins de esclarecimento, o artigo 203 da Constituição Federal diz respeito aos objetivos da política de assistência, e o artigo 204 corresponde às ações na mesma área, especificando que:

As ações governamentais na área da assistência social serão realizadas com recursos do orçamento da seguridade social, previstos no art. 195, além de outras fontes, e organizadas com base nas seguintes diretrizes:

I - descentralização político-administrativa, cabendo a coordenação e as normas gerais à esfera federal e a coordenação e a execução dos respectivos programas às esferas estadual e municipal, bem como a entidades beneficentes e de assistência social;

II - participação da população, por meio de organizações representativas, na formulação das políticas e no controle das ações em todos os níveis. (CONSTITUIÇÃO 1988) 
Os objetivos centrais da política de Assistência Social brasileira, tendo como referência a LOAS, e o artigo 203 da Constituição são: a proteção à família, à maternidade, à infância, à adolescência e à velhice; o amparo às crianças e adolescentes carentes; a promoção da integração ao mercado de trabalho; a habilitação e reabilitação das pessoas portadoras de deficiência e a promoção de sua integração à vida comunitária; a garantia de 1 (um) salário mínimo de benefício mensal à pessoa portadora de deficiência e ao idoso que comprovem não possuir meios de prover a própria manutenção ou de tê-la provida por sua família.

Para Pereira, a atuação da política assistencial, ao estar inserida na relação capital X trabalho, é analisada a partir "de uma contradição fundamental, qual seja: a coexistência da afluência com a pobreza e, portanto, do princípio da rentabilidade econômica com o princípio da atenção às necessidades sociais em um mesmo modo de produção" (PEREIRA, 1996, p.37)

O princípio da rentabilidade econômica tem atuação voltada para o modo de produção capitalista, justificando a lógica da acumulação e tendo como conseqüência a negação ao princípio da atenção às necessidades sociais, visto que este objetiva de maneira geral, a proteção do social. Ou seja, "enquanto o princípio da rentabilidade guia-se pelos critérios da competição e da exploração, o princípio da atenção às necessidades guia-se pelos critérios da cooperação e da justiça distributiva" (PEREIRA, 1996, p. 37)

A partir desses princípios a autora analisa duas vertentes de assistência social, a stricto sensu - focalizada na pobreza absoluta, e a lato sensu - ampliada para o também atendimento da pobreza relativa.

A assistência social stricto sensu segue o princípio da rentabilidade econômica, auxiliando no fortalecimento do capital. Devido à efetivação de ações paliativas e emergenciais, a assistência stricto sensu é muito associada ao assistencialismo. Isso porque, a partir do momento em que a assistência social não é percebida por parte dos governantes como uma prioridade, ela acaba sendo utilizada de forma contingencial,

(...) isto é, eventual e incerta, e por consequiência, é profundamente dependente dos azares do processo de acumulação. Aos primeiros sinais de recessão econômica ou de adoção de medidas de proteção ou de recuperação da economia, ela é imediatamente sacrificada, já que não constitui uma prioridade nacional (...) (PEREIRA, 1996, p.42)

Por outro lado, a política de assistência lato sensu, que remete ao princípio da atenção às necessidades sociais, percebe como fundamental a participação da sociedade 
civil para seu desenvolvimento. Sua integração em projetos de políticas de proteção social além de conferir caráter legal e redistributivo, possibilita uma luta democrática, não restringida a ações imediatas e descontínuas, mas ações e/ou políticas que ampliem direitos sociais. E é a busca pela inclusão dos pobres através da luta pela ampliação de direitos que provoca a formação de conflitos permanentes entre as classes antagônicas.

Devido a tais características voltadas para a área social, a assistência do tipo lato sensu enfrenta dificuldades em sua implementação no modelo neoliberal - defensor do Estado Mínimo no campo da intervenção social. Assim, subtende-se que a vertente stricto sensu, por não ter um comprometimento que seja efetivo e contínuo com a população que vive em situação de vulnerabilidade, é o tipo mais utilizado de assistência social no país.

O provimento de mínimos sociais básicos pelo Estado a pessoas que vivem em situação de miséria é visto de forma negativa pelo modelo neoliberal, o qual acredita que os recursos gastos na área social deveriam ser utilizados para maximizar os lucros da economia do país, e assim, ao produzir mais riqueza, haveria automaticamente uma redução da pobreza no cenário nacional.

Nessa perspectiva, os Estados nacionais deveriam reduzir seu gasto social (diminuindo o investimento em serviços universalizados e direcionando os recursos "disponíveis" para programas assistenciais específicos, destinados apenas aos mais pobres) e, por outro lado, deveriam igualmente reduzir sua "intervenção" na economia, de forma que os acordos comerciais internacionais pudessem ser feitos com mais liberdade, ampliando o mercado e, com isto, reaquecendo a produção e as trocas comerciais agora num plano cada vez mais mundial (VALLA, 2005, p.42).

Esta lógica neoliberal não funciona por um simples motivo: independente de maior ou menor acumulação de riquezas, esta se encontra retida nas mãos de pequena parcela da população (a elite), ou seja, não há redistribuição dos ganhos econômicos, e por esse motivo, é fundamental que haja sim intervenção estatal na área social.

A assistência social não é um fenômeno marginal e transitório, que encontra seu limite na promoção de políticas de emprego e de renda ou na integração dos pobres no mercado de trabalho. Trabalho assalariado, sem assistência social, ou seja, sem a proteção social do Estado como exigência da sociedade, é sinônimo de acumulação primitiva ou de alienação que segundo Marx (1978), não constitui a satisfação de uma necessidade vital, mas apenas um meio de satisfazer outras necessidades, inclusive as do capital (PEREIRA, 1996, p.52). 
A partir disso, e tendo como foco as políticas assistenciais brasileiras, instituídas dentro do modelo neoliberal, infere-se mencionar de modo geral, algumas de suas características, como a focalização na pobreza extrema; a exclusão de indivíduos em situação de vulnerabilidade e que não se encaixam nos requisitos dos programas; e a transferência de renda direta. Ressalta-se, que os indivíduos contemplados nos programas assistenciais precisam estar inseridos em contextos de pobreza, e de extrema pobreza. Estes são estipulados através das linhas de pobreza ${ }^{7}$.

A "distribuição" de renda é uma das principais e mais importantes ações da política de assistência social brasileira, mas vem sendo utilizada como medida paliativa e emergencial. Apesar de não exigir contribuição direta, são estabelecidas várias contrapartidas relacionadas novamente com a renda da população a ser assistida, assim, são geradas sérias conseqüências para os beneficiários. O princípio da menor elegibilidade $^{8}$ e os testes de meio ${ }^{9}$ são bons exemplos de contrapartidas utilizadas para reduzir o acesso dos indivíduos em situação de vulnerabilidade às políticas sociais.

Dentro desse contexto, compete ilustrar que muitas famílias de baixa renda, que devido às suas precárias condições de subsistência deveriam estar recebendo auxilio do Governo, são excluídas dos benefícios por não estarem abaixo da linha de pobreza. Esse fato acarreta uma grande dificuldade em diminuir a pobreza no Brasil, visto que os critérios de renda não abarcam toda a população carente.

\footnotetext{
${ }^{7}$ Em geral, as tentativas de definição de linhas de pobreza se dividem em dois grupos. Por um lado, nos países mais pobres, estão os que buscam estabelecer uma "linha absoluta de pobreza", abaixo da qual as pessoas estariam passando fome, ou em estado de indigência. Isto é feito muitas vezes tentando estabelecer uma equivalência entre renda monetária e a capacidade de compra de um determinado volume de calorias, na suposição de que todo o dinheiro dos pobres é gasto em comida. As diferentes linhas de pobreza que têm sido normalmente propostas para o Brasil, desde os trabalhos pioneiros de Sônia Rocha, são deste tipo. Por outro lado, nos países mais ricos, as linhas de pobreza são de tipo relativo, ou seja, servem para identificar aqueles que têm uma renda ou padrão de vida inferior ao que se considera como um "mínimo aceitável", que varia muito, é claro, de uma sociedade a outra.

${ }^{8}$ O princípio da menor elegibilidade prega que o valor de menor benefício deve ser inferior ao do pior trabalho e visa "diminuir ao máximo as chances de merecimento do pobre à assistência social." (PEREIRA, 1996, pág.62)

${ }^{9}$ Os testes de meios são seleções que separam "no próprio âmbito da pobreza, os merecedores dos nãomerecedores da provisão, com consequiências adversas para ambos: enquanto os últimos ficam no desamparo, os primeiros são estigmatizados pelo fato de merecer. (PEREIRA, 1996, pág.64)
} 
Assim, os indivíduos não incluídos nos programas assistenciais do Governo, por não possuírem estimativas na melhoria de vida, ficam à margem da sociedade, permanecendo muitas vezes nas ruas dependendo da "boa vontade" de outros cidadãos para sua sobrevivência. Isso gera no senso comum a solidificação do estigma de marginal, preguiçoso, acomodado, que marca essa população. Tais estigmas e rótulos vistos na sociedade atual em relação à pobreza podem ser retomados à antiga noção de que o pobre é avesso ao trabalho.

A partir do que foi dito, e tendo como objetivo geral deste trabalho entender a relação dos organismos do Governo do DF que atuam em parceria na execução das políticas sociais voltadas à população de rua, se faz necessária uma breve descrição a respeito da formação e intensificação desta população nas cidades. 


\title{
CAPÍTULO II
}

\section{O Fenômeno da População de Rua}

\begin{abstract}
“O que faz época na história da acumulação primitiva são todos os revolucionamentos que servem de alavanca à classe capitalista em formação; sobretudo, porém, todos os momentos em que grandes massas humanas são arrancadas súbita e violentamente de seus meios de subsistência e lançadas no mercado de trabalho como proletários livres como os pássaros" (MARX, 1984, pag.341).
\end{abstract}

O fenômeno da população de rua não deve ser considerado originário da modernidade. De acordo com Marx, desde a separação entre o produtor e o meio de produção "uma massa de proletários livres como os pássaros foi lançada no mercado de trabalho" (MARX, 1984, pag. 343). Entretanto, a nascente indústria manufatureira, não conseguia absorver tamanha mão de obra e, em decorrência dos fatos citados, deu-se início a um crescente pauperismo da classe trabalhadora que, por não possuir meios de sobrevivência, ficou à margem da sociedade.

As mudanças ocorridas no mundo entre o final do século XIII e início do século XIV - queda do feudalismo ao início do capitalismo -, foram decisivas para a efetivação das divisões sociais que perduram até os dias de hoje.

No feudalismo a economia era baseada na agricultura e, apesar da intensa exploração dos senhores para com os servos, havia uma relação de dependência entre ambos. Os primeiros, que trabalhavam e sobreviviam da terra, eram obrigados a prestar serviços à nobreza e a pagar-lhes diversos tributos. Em troca, os senhores forneciam proteção militar aos camponeses.

As condições de vida nessa época não eram as ideais: a alimentação e os hábitos de higiene não propiciavam qualidade na vida da população. É importante observar que o trabalho no campo proporcionava aos camponeses apenas o mínimo necessário para sua sobrevivência.

(...) durante a Idade Média, não se podia encontrar conforto em parte alguma, mas alimento em toda parte. Numa época em que quase toda a população vivia a partir do solo, a pobreza e as maneiras rudes podiam coexistir, mas as necessidades mais básicas do homem podiam ser supridas. É raro a terra não fornecer o suficiente para amainar a fome de quem quer que nela trabalhe. A população era pobre, mas vivia. Hoje, a 
maioria é mais feliz, mas morreria de fome caso não houvesse a caridade pública (TOCQUEVILLE, 2003, p.85).

Contudo, a expulsão dos trabalhadores das terras feudais acarretou diversas consequiências que afetaram o modo de vida existente: a migração da população rural para as cidades em busca de oportunidade de trabalho, se tornou uma das causas iniciais da consolidação da pobreza na era do capital.

A destituição dos meios de produção, a falta de capacitação e a não absorção da mão de obra rural pelo mercado de trabalho, fizeram com que os camponeses - agora "trabalhadores livres" 10 - se tornassem excluídos da nova conjuntura social. Essa exclusão dá início a um agravamento das desigualdades sociais, que terá como uma de suas conseqüências mais graves a marginalização desse grupo social. Nesse momento faz-se necessário iniciar uma discussão a respeito do conceito do que vem a ser a população de rua, visto que tal conceito é tratado e entendido de diversas formas devido aos diferentes contextos históricos existentes. A partir disso, pode-se dizer que população de rua é um fenômeno social antigo que

constitui uma síntese de múltiplas determinações, cujas características, mesmo com variações históricas, o tornam um elemento de extraordinária relevância na composição da pobreza nas sociedades capitalistas. (SILVA, 2006, p.76)

A heterogeneidade da população de rua dificulta a efetivação de um consenso para a criação de um único conceito desta categoria. Assim, é normal a associação de palavras como mendigo, pedinte, flanelinha, viciado, maltrapilho, pessoa em situação de rua, migrante, e andarilho, a esses indivíduos. O estigma e o preconceito carregados por esses termos exigem suas diferenciações, ou, em outras palavras, não se pode igualar a situação de todas as pessoas que se encontram na rua: há os que trabalham, os que mendigam, os que roubam, os que se drogam, assim como em qualquer outra categoria ou classe social.

De acordo com Camila Potyara Pereira, pode-se definir população de rua como: grupo populacional de composição heterogênea, mas que possui em comum a pobreza extrema, a ausência de moradia convencional regular e que pernoita de maneira

\footnotetext{
${ }^{10}$ Termo utilizado por Marx em "O Capital” (1984)
} 
contumaz em logradouros públicos, espaços degradados ou abandonados, terrenos baldios ou outras áreas não-urbanizadas elou instituições de abrigamento e acolhida. ${ }^{11}$

A partir da noção de que os termos anteriormente citados exercem muitas vezes valores pejorativos, nessa pesquisa será utilizada a terminologia "população de rua" para se referir às pessoas que vivem na e da rua, que tiram seu sustento a partir de trabalhos precários como, vigiar e lavar carros, catar latinha, vender doces. Pode-se também caracterizar como população de rua, pessoas que migram para centros urbanos em busca de trabalho, e por vários motivos -, como a pouca renda que auferem, o que impede o gasto com locomoção -, acabam permanecendo a maior parte do tempo nas ruas, retornando para suas residências em determinadas épocas do ano, ou somente quando é possível (PEREIRA, 2009).

\section{Histórico da População de Rua}

Na Europa do século XVI e XVII, uma série de acontecimentos referentes às guerras, proliferação de doenças, crises internacionais e desapropriações de terras, marcaram a generalização da miséria entre a classe trabalhadora. Entende-se por esta, os servos, camponeses, artesões, pequenos agricultores, entre outros.

A superação do feudalismo deu início ao modo de produção capitalista, também chamado, em sua primeira fase, de acumulação primitiva, por constituir a pré-história do capital. Essa fase é caracterizada como o processo histórico no qual o trabalhador é dissociado dos meios de produção a partir da venda e exploração de sua força de trabalho pelos burgueses.

Do século XVI ao final do século XVIII, a Europa passou por um período de expansão econômica que abriu novos horizontes aos comerciantes. O aumento do intercâmbio comercial a partir da construção de novos tipos de embarcações foi um dos fatores fundamentais para o desenvolvimento do comércio. A exploração de novas terras e a intensificação da procura por metais preciosos marcam o estabelecimento da Revolução Comercial (HUBERMAN, 1986).

\footnotetext{
${ }^{11}$ Conceito exposto em aula de orientação.
} 
Uma forte conseqüência deste período, devido às grandes retiradas de metais preciosos das colônias Européias, foi a alta nos preços. Quanto maior a quantia de dinheiro em circulação, maior eram os preços dos produtos, acarretando no estabelecimento da Revolução dos Preços. Esta foi uma crise econômica de amplitude internacional, em que a burguesia obteve vantagens, mas a classe trabalhadora foi extremamente prejudicada. (HUBERMAN, 1986)

Essa crise, ao gerar consequiências negativas para os proprietários de terra, que viviam de rendas produzidas a juros fixos (pensões, anuidades), desencadeou uma elevação dos arrendamentos, que culminou na desapropriação das terras pelos arrendatários, os lavradores pobres.

$\mathrm{O}$ movimento de fechamento das terras provocou muito sofrimento, mas ampliou as possibilidades de melhorar a agricultura. E quando a indústria capitalista teve necessidade de trabalhadores, encontrou parte da mão-de-obra entre esses infelizes desprovidos de terra, que haviam passado a ter apenas a sua capacidade de trabalho para ganhar a vida (HUBERMAN, 1986, p.108).

Assim, ao perder os meios de subsistência, esses indivíduos foram jogados à própria sorte. Sem trabalho e sem ter para onde ir, a maioria passou a viver nas ruas, sobrevivendo dos restos da sociedade, que, por sua vez, os rotulou de vadios, mendigos, e incapacitados.

[...] os que foram bruscamente arrancados de seu modo costumeiro de vida não conseguiam enquadrar-se de maneira igualmente súbita na disciplina da nova condição. Eles se converteram em massas de esmoleiros, assaltantes, vagabundos, em parte por predisposição e na maioria dos casos por força das circunstâncias. (MARX, 1984, pag.356)

A destituição dos meios de produção contribuiu para o processo de marginalização da classe trabalhadora, assim como também para o consequiente crescimento do número de indigentes nos centros urbanos. Tal situação se mantém presente na atualidade demonstrando sua inerência ao sistema capitalista ${ }^{12}$.

\footnotetext{
${ }^{12}$ É importante identificar uma curiosidade encontrada em países mais desenvolvidos: há uma grande taxa de indigentes quando comparado aos países mais pobres. Isto se deve ao fato de que, onde há riqueza, é possível viver melhor, seja qual for a situação do indivíduo. Em um país rico, as doações são mais constantes, até o lixo, que deveria ser desprezado, representa fonte de renda para os desprovidos.
} (TOCQUEVILLE, 2003) 
O aumento do número de indigentes acarretou na elaboração de diversas Leis que tinham como objetivo agir de forma repressiva contra os indivíduos não inseridos no mercado de trabalho. Considerando as principais iniciativas do Estado no que se refere à repressão e regulação dessa população, pode-se destacar:

- $1388-1^{\mathrm{a}}$ Lei dos pobres - Foi aplicada de forma autônoma em diversas paróquias; o adulto em boas condições de trabalho só poderia receber ajuda se em troca aceitasse uma atividade laboral.

- 1601 - Poor Law - Primeira Legislação específica que unificava Leis anteriores. Responsabilizava as paróquias por seus pobres, dividindo os mesmos em merecedores de assistência, e não merecedores. Usava da coesão e tipologia para caracterizar os indivíduos: os aptos ao trabalho iam para as workhouses; os inaptos para as poorhouses; e os corruptos, que tinham condições, mas não queriam trabalhar, para as almhouses; todas estas tinham em comum a semelhança com prisões.

- 1662 - Settlement Act (Lei de resistência) - Impedia que os trabalhadores se deslocassem "para Paróquias mais atraentes quanto à remuneração do trabalho, assim como dava aos magistrados locais o direito de devolver ao seu lugar de origem qualquer recém-chegado que onerasse os cofres públicos." (PEREIRA, 2008, pag.65)

- 1795 - Speenhamland Law - Lei baseada no preço do pão. Foi a $1^{\text {a }}$ Lei de transferência de renda, o Estado tinha a obrigação de pagar uma taxa complementar aos baixos salários para que os trabalhadores não obtivessem um rendimento mensal abaixo do mínimo. Por ser contrária a lógica capitalista, a Lei não obteve sucesso, visto que ao subsidiar baixos salários, estes foram achatados pelos empregadores, o que culminou em um impedimento no desenvolvimento de mercado devido aos investimentos que o Estado deixava de fazer na economia.

- 1834 - Poor Law Amendment Act - É importante destacar que esta foi a lei mais severa já implementada e, que suas características perduram até hoje na formulação de novas leis. O principal objetivo da Poor Law Amendment Act era auxiliar o crescimento do capitalismo, para isso 
destinava-se a liberar mão de obra para o mercado de trabalho, através das workhouses. A ideologia de Malthus (1983) foi a base desta Lei. Na Poor Law Amendment Act a assistência social tinha caráter punitivo e vínculo com trabalho.

Para ilustrar a maneira repressiva na qual a população marginalizada foi tratada, farei referência a uma passagem de Marx, em que este cita o surgimento em toda a Europa ocidental, no final do século XV e durante todo o século XVI, de uma legislação "sanguinária contra a vagabundagem":

$\mathrm{Na}$ Inglaterra, essa legislação começou sob Henrique VII.

Henrique VIII, 1530: Esmoleiros velhos e incapacitados para o trabalho recebem uma licença para mendigar. Em contraposição, açoitamento e encarceramento para vagabundos válidos. Eles devem ser amarrados atrás de um carro e açoitados até que o sangue corra de seu corpo, em seguida devem prestar juramento de retornarem a sua terra natal ou ao lugar onde moraram nos últimos 3 anos e "se porem ao trabalho" (to put himself to labour). Que cruel ironia! [...] o estatuto anterior é repetido mas agravado por novos adendos. Aquele que for apanhado pela segunda vez por vagabundagem deverá ser novamente açoitado e ter a metade da orelha cortada; na terceira reincidência, porém, o atingido, como criminoso grave e inimigo da comunidade, deverá ser executado (MARX, 1984, pag. 356).

A partir da citação acima, e tendo a Lei Poor Law Amendment Act como referência, cabe elucidar, de maneira sucinta, como se dava o trabalho nas workhouses. Nesta fase, estas instituições se caracterizavam por extrema precariedade, tanto na alimentação, como nas vestimentas, nas condições e intensidade do trabalho, e no horário de descanso. Ao entrar em uma workhouse a família era separada. Crianças, mães, e pais, provavelmente nunca mais se reencontrariam. Ao sofrer qualquer tipo de acidente nas workhouses, haveria uma substituição imediata do operário, que não tinha direito a nenhum tipo de benefício ou auxílio dos patrões, pois o único responsabilizado por tais acidentes era o próprio trabalhador.

Em vista disso, a sobrevivência nas ruas das grandes cidades, apesar de muito difícil, era uma alternativa melhor que o trabalho nas workhouses. Estas tinham um forte papel higienista, entendendo que, ao retirar das ruas os indigentes, vagabundos e marginais, e realocando-os nas casas de trabalho, resolveriam o problema da pobreza em seus vários âmbitos: dos ricos, que não teriam mais que conviver com esses 
indivíduos; dos pobres, que teriam suas necessidades "atendidas" em troca de trabalho; e também das próprias cidades, que se encontrariam livre de toda poluição visual.

Nesse contexto, o desenvolvimento de tecnologias e a alteração no modo de produção propiciaram a consolidação da Revolução Industrial, que em seu turno causou uma transformação nos valores da sociedade. A introdução do uso de máquinas fez com que estas assumissem um papel central na produção, ao contrário do trabalho humano, que foi reduzido e desvalorizado. A grande oferta de mão de obra composta pelos antigos trabalhadores rurais proporcionou ao capitalismo um exército reserva de mão de obra barata, visto que, ao não possuir meios de produção, os trabalhadores necessitavam vender sua força de trabalho para sobreviver.

\section{A origem do fenômeno população de rua no Brasil}

A ocorrência e o crescimento da pobreza no Brasil e o conseqüente aumento do número de indigentes não se diferencia muito de outros países. Partindo do contexto do modo de produção capitalista, cabe descrever quais os pontos principais que desencadearam a acentuação da pauperização da classe trabalhadora no país. De acordo com Lícia Valadares (1990), a trajetória da urbanização tem forte relação com as mudanças no mercado de trabalho e também com a inserção da população pobre nas grandes cidades.

O início do modo de produção capitalista no Brasil - virada do século XIX -, acarretou mudanças nas relações sociais, que deixaram de ser entre escravos e senhores, para ser do tipo burguês-capitalista. Os ex-escravos passam a ser incentivados a ver o trabalho como algo positivo para, assim, poderem se inserir no sistema fabril, como forma de mão de obra barata.

Para tanto o conceito de trabalho precisava se despir de seu caráter aviltante e degradador - característico de uma sociedade escravista - e ganhar uma valoração positiva. Era preciso incutir uma nova ideologia do trabalho - sobretudo entre os que carregavam nas costas a experiência da escravidão - tentando articular a mesma aos conceitos de ordem e progresso que inspiravam a recém-criada República. Era necessário fazer com que o liberto "amasse" o trabalho em si, independentemente das vantagens materiais que pudessem daí advir. Era fundamental transmitir ao liberto que o trabalho é o valor supremo da vida em sociedade, que o mesmo é o elemento característico da vida "civilizada". (VALADARES, 1990, pag.89) 
A sociedade foi dividida em dois mundos distintos: o do trabalho, referente à nova ordem econômica, que distanciava os indivíduos da pobreza, ou ao menos da condição de miserável; e o mundo dos vadios - pessoas que recusavam o assalariamento, vivendo em meio ao ciclo da pobreza, entendido como viciante.

O crescimento desregrado das áreas urbanas em meio às péssimas condições de saneamento, higiene, distribuição de água, entre outros, principalmente nas áreas mais carentes, desencadeou um novo problema para a elite da época. Nesse contexto, questões relativas à saúde impuseram a necessidade de higienização das cidades como forma de manter a ordem social.

O Rio de Janeiro foi considerado a capital das epidemias, geradas pelas péssimas condições sanitárias e habitacionais da população. A população pobre, que residia em cortiços insalubres se via em uma situação extremamente deplorável.

A propagação das doenças relacionava-se diretamente às catastróficas condições de higiene às quais estava submetida grande parte da população. Vivendo em habitações coletivas precárias - estalagens, casas de cômodos e sobretudo em cortiços - era diário o convívio com sérias falhas no abastecimento d'água e com péssimas condições de saneamento básico (VALADARES, 1990, pag.84).

Intensifica-se, a partir disso, o preconceito e rejeição às pessoas que vivem nos cortiços, por este ser um lugar que serve de moradia para vadios, ladrões e viciados, todos rotulados como não trabalhadores. Sendo assim, esses locais são considerados como geradores de pobreza e desordem, além de grandes propagadores de doenças.

Começa-se então, a intervir sobre a pobreza de maneira a impor medidas higienistas como forma de proteção a toda população. $\mathrm{O}$ fechamento e a proibição da criação de novos cortiços, assim como a execução de campanhas sanitárias, foram algumas das ações tomadas pelo governo como forma de frear o crescimento das epidemias.

Contudo, o desenvolvimento dos centros urbanos não foi capaz de conciliar o inchaço populacional e a criação de empregos para o novo contingente. Assim, pode-se notar tanto o crescimento do trabalho informal, como também a precarização das condições de vida nas cidades. A pobreza passou a ser encarada como problema social, que se desenvolve a partir do aumento do subemprego, tido como definidor daquela. 
Nesse contexto, a sociedade passou a ser responsabilizada em grande medida pela condição de marginalidade que se encontrariam os indivíduos excluídos do mercado de trabalho. A insuficiência de absorção da grande mão de obra - o exército reserva - deixa visível que o fato de não ter trabalho é diferente de não querer trabalho. Isso mostra a visão positiva que o trabalho passou a ter na vida dos indivíduos, exercendo um papel de centralidade que ganhará maior valorização por meio da criação das legislações trabalhistas. Estas passaram a estabelecer os direitos da classe trabalhadora, assim como a regulamentar suas atividades. Outra conseqüência das medidas de proteção aos trabalhadores foi o estabelecimento de uma nova divisão social: os assalariados e os não-assalariados.

Pobreza torna-se sinônimo de carência, situação em que o atendimento das necessidades biológicas e sociais dos indivíduos ou de suas famílias está abaixo de um patamar mínimo. A partir deste novo princípio classificatório torna-se possível diferenciar grupos no interior da população pobre: aqueles acima ou abaixo da linha da pobreza; aqueles com ou sem renda regular medida em termos de salário-mínimo (VALADARES, 1990, pag.100).

O salário-mínimo propiciou então, a diferenciação entre pobres, e pobres em situação de miséria. Estes últimos são identificados por receberem uma renda abaixo de um quarto do salário-mínimo e, por essa condição, passam a ter direito a participar dos programas sociais de combate à pobreza, entretanto, cabe expor, que outras condicionalidades impostas a esses indivíduos impedem sua inserção nos programas citados.

Ao mesmo tempo em que é difícil se encaixar nos critérios para a participação nos programas sociais, basta que a renda familiar ultrapasse 1/4 do salário mínimo para que o indivíduo esteja automaticamente fora dos programas em questão. Em outras palavras: a pessoa estará novamente sem a proteção do Estado. Nesse contexto, encontra-se a população de rua, que além de não pertencer ao mercado de trabalho formal é estigmatizada e excluída da sociedade. Tal afirmação pode ser justificada pela visão de que esta população está na situação de vulnerabilidade por vontade própria, pelo julgamento de que é mais fácil viver esmolando do que ter um trabalho digno.

O processo de consolidação industrial do Brasil ocorrido na década de 70 ocasionou diversas conseqüências para a classe trabalhadora. $\mathrm{O}$ crescimento da economia surgiu paralelo a uma acentuação das desigualdades sociais, em que a 
periferização dos trabalhadores pode ser tida como exemplo. Estes foram (e permaneceram) excluídos dos centros urbanos, onde somente deveriam estar durante o período de trabalho.

Apesar da mudança de contexto e de significados em que a classe trabalhadora se viu inserida, os moradores da periferia passaram a ser vistos como os antigos residentes dos cortiços, sofrendo os mesmos preconceitos e dificuldades, porém em uma nova conjuntura social.

É nesse cenário, marcado pela consolidação de uma ofensiva neoliberal ${ }^{13}$ que se tem, não só um crescente processo de periferização nas cidades ${ }^{14}$, bem como, e em conseqüência disso, um aumento considerável do número de pessoas que vivem nas ruas, seja por falta de habitação (o que nos remete à questão da terra e à noção de propriedade privada), seja ancorada na busca de um lugar que esteja mais próximo ao local de trabalho, ou ainda, pelo fato de essa mesma pessoa sequer ter a oportunidade de possuir um trabalho formalizado.

Desse modo, destaca-se que a população de rua é invisível aos olhos da sociedade, que só a percebe em momentos de conflitos de interesse, como por exemplo, quando a elite se depara com moradores de rua perto de suas residências, fato que incomoda e gera repulsa.

\section{População de Rua do Distrito Federal}

No ano de 1956 com a eleição de Juscelino Kubitschek para a presidência da república, foi lançado o Plano de Metas, que teve o slogan "50 anos em 5" para representar 50 anos de progresso em 5 anos de mandato. Através desse Plano foi colocado em prática o antigo sonho de transferir a capital do Brasil.

\footnotetext{
${ }^{13}$ A ofensiva neoliberal é caracterizada pelo enxugamento da máquina estatal; desresponsabilização do Estado e transferência de responsabilidades para a sociedade civil; consolidação dos preceitos de liberdade individual e propriedade privada.

${ }^{14}$ A periferização das cidades pode ser configurada em decorrência das intensas migrações e inchaços populacionais, principalmente nas regiões de importância econômica histórica, como é o caso do CentroSul.
} 
A construção da nova capital atraiu trabalhadores de vários estados, que migraram para a cidade em busca de emprego. Os candangos - apelido dos trabalhadores da nova Capital - não puderam permanecer como moradores da tão sonhada cidade modernista, e foram mandados embora da área urbana antes da inauguração da cidade.

(...) não mais servindo ao projeto de construção da nova capital, uma vez conclusa, os operários deveriam dela sair, em data estipulada para a inauguração da cidade. A construção da cidadania é assim vinculada, contraditoriamente, à não-cidadania do homem pobre e livre, dependente do senhor territorial, detentor do monopólio privado do poder, para usufruir seus direitos (VELOSO apud SALES, 1994).

Desde sua criação, como foi citado acima, Brasília já dava início à grande disparidade econômica e social vista facilmente nos dias atuais. “(...) o processo de exclusão dos trabalhadores, iniciado na construção da cidade, toma nova forma no tempo presente, quando inúmeros migrantes sem-teto, povoam as vias da cidade, ainda em busca de trabalho e sobrevivência" (VELOSO, 2007, p.5).

Em 1988, Joaquim Roriz, então Governador do Distrito Federal, deu início a uma política de distribuição de lotes para famílias desalojadas, que se encontravam morando de forma precária no Plano Piloto - área central do DF. Esta política visava à retirada de favelas e acampamentos irregulares no centro de Brasília, e acabou por atrair uma quantidade enorme de migrantes que vinham à Capital em busca de moradia. A partir disso, diversas cidades foram criadas ao redor do DF. Estas ficaram conhecidas pelo nome de cidades satélites e representam a periferia da Capital. Atualmente as cidades satélites converteram-se em Regiões Administrativas (RAs), sendo que, na atualidade, existem 30 RAs no Distrito Federal. ${ }^{15}$

\footnotetext{
${ }^{15}$ O Distrito Federal subdivide-se em 30 Regiões Administrativas: RA I Brasília; RA II Gama; RA III Taguatinga; RA IV Brazlândia; RA V Sobradinho; RA VI Planaltina; RA VII Paranoá; RA VIII Núcleo Bandeirante; RA IX Ceilândia; RA X Guará; RA XI Cruzeiro; RA XII Samambaia; RA XIII Santa Maria; RA XIV São Sebastião; RA XV Recanto das Emas; RA XVI Lago Sul; RA XVII Riacho Fundo; RA XVIII Lago Norte; RA XIX Candangolândia; RA XX Águas Claras; RA XXI Riacho Fundo II; RA XXII Sudoeste/Octogonal; RA XXIII Varjão; RA XXIV Park Way; RA XXV SCIA - Setor Complementar de Indústria e Abastecimento; RA XXVI Sobradinho II; RA XXVII Jardim Botânico; RA XXVIII Itapoã; RA XXIX SIA - Setor de Indústria e Abastecimento; RA XXX Vicente Pires.
} 
O contraste de classes em Brasília é mais fácil de ser visualizado quando é feita uma comparação entre o Plano Piloto e as demais RAs, visto que estas são compostas, em sua maioria, por trabalhadores de classes baixas, enquanto aquela, residida pela elite, mantém em sua infra-estrutura um forte controle segregacionista. Pode-se citar como exemplo desta segregação o fato de que o padrão de vida no centro de Brasília é alto o suficiente para não "permitir" a residência desses trabalhadores na área nobre da capital.

Se por um lado, os trabalhadores pobres têm a possibilidade de se manter em cidades ao redor do Distrito Federal, o mesmo não pode ser dito a respeito da população de rua da capital que, ao não possuir trabalho regular, acaba por morar nos logradouros da cidade, sobrevivendo de trabalhos precários e de doações. As residências desses indivíduos são fixadas fora da visibilidade da classe alta, ou em lugares mais espaçados, como campos abertos ou abandonados. "Os sem-teto habitam territórios inimagináveis como, por exemplo, um acampamento de sem-teto nos fundos do Palácio do Planalto" (VELOSO, 2007, pag.2).

Implica-se então que os acampamentos irregulares tanto do entorno, como dentro do Plano Piloto acarretam pelo menos duas formas de julgamentos relativos à sua visualização: no primeiro caso, o fato de os acampamentos serem fora do centro da cidade produz a falsa idéia que não há disparidades no Plano Piloto; e o segundo, se refere à população de rua que vive na área nobre de Brasília. Esta população é estigmatizada ao ser percebida como formada por marginais, drogados, vagabundos, e não por trabalhadores, o que efetivamente são na maioria dos casos.

A concepção de marginalidade construída em referência a estes indivíduos corrobora para a execução de ações coercitivas do Governo sem que os abusos cometidos sejam percebidos pela "elite" residente do Plano Piloto.

Dentro do que foi exposto, cabe citar o sistema de controle da população de rua existente no Governo do Distrito Federal que, nessa pesquisa, teve como foco de análise, a Subsecretaria de Defesa do Solo e da Água (SUDESA), responsável pelas remoções dos acampamentos irregulares presentes no Plano Piloto, e a Secretaria de Estado de Desenvolvimento Social e Transferência de Renda (SEDEST). Esta, de forma geral, é encarregada de efetuar o cadastramento da população de rua para que seja 
possível a verificação das demandas desses indivíduos e o posterior encaminhamento a determinados programas sociais.

Ressalta-se que através da realização do trabalho de campo, foram obtidas indicações de que as finalidades dos organismos em referência, em certa medida, vêm sendo cumpridas. Entretanto, a falta de articulação entre as mesmas, foi averiguada por meio das entrevistas com os funcionários das instituições, e também pelos depoimentos da população de rua.

As políticas sociais, que deveriam cumprir o papel de garantidoras de direitos, continuam a ser implementadas de forma higienista. Isso pode ser comprovado ao se analisar as políticas sociais efetivadas no DF, que ao invés de agir na resolução dos problemas de intensificação da pobreza, acabam por utilizar medidas paliativas, gerando um ciclo vicioso e sem eficiência para os dois lados - Governo e população.

Percebe-se ainda a necessidade de desmistificação do pobre como vadio e mau elemento. Este deve ser encarado como vítima do modo de produção capitalista, caso contrário não será possível obter mudanças na maneira com que estes indivíduos são tratados. 


\section{CAPÍTULO III}

\section{Correlação de Forças: Governo x População de rua}

A partir do que foi apresentado nos capítulos anteriores, faz-se necessário descrever como se deu o trabalho de campo. Os dados apresentados a seguir foram obtidos entre o $2^{\circ}$ semestre de 2009 e o $1^{\circ}$ semestre de 2010. Para a coleta de informações, foi estabelecido contato com: a Secretaria de Estado de Desenvolvimento Social e Transferência de Renda - SEDEST; a Subsecretaria de Defesa do Solo e da Água (SUDESA); o Albergue Conviver - ALBERCON; quatro indivíduos que residiam em ruas próximas à Companhia de Saneamento Ambiental do Distrito Federal CAESB, e à Universidade de Brasília - UnB; e três pessoas que utilizavam os serviços do referido albergue.

As entrevistas realizadas tiveram o objetivo de identificar como são feitas as retiradas da população de rua do Plano Piloto dos acampamentos ${ }^{16}$ irregulares, e qual acompanhamento e/ou encaminhamento estes sujeitos recebem. Além disso, buscou-se entender como é a relação entre a SUDESA e a SEDEST, e se estas mantêm algum tipo de articulação. A participação da população de rua e dos albergados foi fundamental para comparar o que as instituições dizem oferecer, e o que de fato é feito para retirar tais indivíduos da situação de vulnerabilidade a qual estão expostos.

É importante deixar claro que as informações contidas na presente pesquisa são referentes à época das entrevistas. Nas instituições citadas foram entrevistadas pessoas "chaves", ou seja, que ocupavam cargos ou posições centrais e que, por isso, tinham um maior conhecimento sobre o funcionamento da própria instituição e a forma de atendimento ou atenção prestados à população de rua. Entretanto, não se pode generalizar suas respostas e entendimentos como algo que seja seguido pelas instituições.

\footnotetext{
${ }^{16}$ É importante esclarecer que o termo "acampamento" é utilizado pela população de rua de Brasília, para se referir ao local que habitam no interior do Plano Piloto, ou seja, nas áreas desabitadas do cerrado. O Governo do Distrito Federal por sua vez, se refere aos acampamentos como "invasões".
} 


\section{SUBSECRETARIA DE DEFESA DO SOLO E DA ÁGUA (SUDESA)}

"Não há envolvimento social, a responsabilidade da SUDESA é a erradicação”. (fala do Subsecretário da SUDESA)

Conforme já foi esclarecido neste trabalho, a principal responsabilidade da SUDESA é a erradicação das ocupações irregulares de área pública que têm a moradia como finalidade. Outros tipos de "invasões", como as de ambulantes para comércio, por exemplo, não fazem parte da atuação desta Subsecretaria. Isso pode ser comprovado na fala do Subsecretário, segundo o qual, a SUDESA é coordenadora operacional da Força Tarefa, uma espécie de colegiado em que vários órgãos do GDF são designados para atuar em uma demanda muito grande, que no caso da SUDESA é a ocupação ilegal de terra.

As operações são marcadas a partir de declaração de ocupação irregular de área pública, através de denúncias e de ofícios. Um levantamento pré-operacional é realizado e, após o diagnóstico, são repassados para outros órgãos os encaminhamentos que forem necessários, como por exemplo, para a CEB é informado que há gambiarras de energia no local da ocupação, para a SEDEST que existem famílias que precisam de proteção social, e assim sucessivamente.

O Subsecretário informou que a maior demanda nas retiradas executadas no Plano Piloto é referente aos acampamentos irregulares dos catadores de material reciclável, visto que, por ser uma área de grande poder aquisitivo, o Plano Piloto produz um lixo mais "rico" quando comparado às outras cidades do entorno do DF. Sendo assim, a eficácia das remoções se caracteriza como um ponto problemático para a Subsecretaria. Entretanto, apesar das dificuldades, o entrevistado acredita que dentro da percepção da instituição, tem havido diminuição das ocupações em comparação com o primeiro ano do Governo Arruda. Acrescentou que a eficácia nas ações não é maior porque grande parte da população de rua retorna aos acampamentos, fato que exige freqüentes remoções.

É um processo de longo prazo, a reciclagem só pode melhorar se o Estado (e a sociedade) assistirem melhor essas pessoas. Enquanto isso não acontece, não há como deixar as invasões tomarem conta da cidade (sic).

Segundo o entrevistado, "seria necessário quadruplicar as equipes" para acabar com as ocupações de terra, contudo isso resolveria o problema de forma imediata, mas 
não funcionaria definitivamente. De acordo com ele, se houvesse um tipo de penalidade legal para quem vive nos acampamentos, o trabalho da Subsecretaria seria mais eficaz, visto que os indivíduos teriam que responder por tais atos. Como essa não é a realidade, o declarante afirmou que não há como evitar novas ocupações, pois o material da coleta vai continuar existindo.

Tendo em vista que os acampamentos são constituídos em grande parte, por famílias de catadores, foi esclarecido que, no caso de haver menores no local da remoção, a Vara da Infância é acionada para tomar as medidas necessárias. Na opinião do entrevistado, as crianças são usadas como "escudo" para evitar que a retirada seja efetivada. Em contradição a esta declaração, existem relatos de que as crianças que moram nos acampamentos irregulares não possuem seus direitos respeitados, havendo vários casos de pais que tiveram seus filhos levados para abrigos. Cabe destacar o Art.23 do Estatuto da Criança (ECA), no qual a falta ou a carência de recursos materiais não constitui motivo suficiente para a perda ou a suspensão do poder familiar.

Parágrafo único. Não existindo outro motivo que por si só autorize a decretação da medida, a criança ou o adolescente será mantido em sua família de origem, a qual deverá obrigatoriamente ser incluída em programas oficiais de auxílio.

Ao serem levadas de suas famílias, as crianças correm o risco de perderem contato com os pais, visto que estes não possuem dinheiro para visitá-las nas instituições. Acrescenta-se que, de acordo com as entrevistas realizadas com a população de rua dos acampamentos, não foram encontradas crianças fora da rede pública de ensino, fato que reforça o Art.23 do ECA.

Após o reconhecimento do local da ocupação e da retirada das famílias, o trabalho de encaminhamento e realocação dos catadores é realizado pela equipe da SEDEST, mais especificamente pelo Núcleo de Proteção em Situação de Calamidades Públicas e de Emergências (NUCPS). Apesar de afirmar que na Força Tarefa cada órgão executa sua função, o Subsecretário disse que a relação entre a SUDESA e a SEDEST é vista como positiva. No que se refere à articulação entre as mesmas, deve ficar claro que a SUDESA só coordena as remoções, e que cada órgão tem competência para executar suas atribuições específicas, ou seja, a articulação é feita para organizar a retirada, mas não há retorno para nenhuma das partes. O que acontece é uma verificação posterior para saber se ocorreram novas ocupações irregulares no local. 
A constância das remoções, de acordo com o subsecretário, não gera nenhum tipo de frustração na equipe da SUDESA. Os profissionais da Subsecretaria são capacitados para lidar com esse tipo de situação, pois, antes de cada ação é realizado um planejamento no qual a equipe é orientada a como agir na futura remoção. Salientou, entretanto que, por envolver interesses distintos, as ações podem ser consideradas como geradoras de conflitos, fato que não justifica o uso de violência por nenhuma das partes.

Ainda segundo o entrevistado, quando há casos de denúncias contra a equipe da Subsecretaria, são abertos processos públicos na corregedoria de polícia, abertos para consulta pública.

\section{SECRETARIA DE ESTADO DE DESENVOLVIMENTO SOCIAL E TRANSFERÊNCIA DE RENDA (SEDEST)}

As entrevistas efetuadas na SEDEST, tiveram o objetivo de colher informações a respeito das políticas públicas oferecidas para a população de rua do Distrito Federal, assim como também, entender se existe articulação nas ações desta Secretaria com a Subsecretaria de Defesa do Solo e da Água - SUDESA. Para isso, foi necessária a realização de entrevistas em dois Núcleos da SEDEST: o Núcleo Especializado de Abordagem Social em Espaços Públicos - NUASO, e o Núcleo de Proteção em Situação de Calamidades Públicas e de Emergências - NUCPS.

\section{NUASO}

"A sociedade reclama, mas mantém os moradores de rua. Ela faz doações, seja em dinheiro, comida, roupa..." (fala da coordenadora do NUASO)

Neste Núcleo, o trabalho de campo se deu em dois momentos: um no segundo semestre de 2009, e outro em janeiro de 2010. Questões que envolvem a Política de Assistência Social voltada para a população de rua do DF, ações do Governo na área social, estrutura para a efetivação das ações, demandas atendidas, e articulações da Secretaria, foram levantadas durante a conversa com as Secretárias do Núcleo.

O trabalho desenvolvido pelo NUASO abrange todo o DF. Segundo a entrevistada, as atividades são de caráter educativo, ou seja, o objetivo não é a repressão, mas sim, a proteção da população de rua. A identificação das demandas dessa população, como a falta de moradia, desemprego, situação de drogadição, entre outros, 
é realizada através de um processo de aproximação $\left(\right.$ abordagem $^{17}$ ) e criação de vínculo ${ }^{18}$ entre os profissionais do NUASO - educadores e agentes sociais - e a população de rua. Quando o indivíduo aceita o acolhimento, os encaminhamentos para área de saúde, casas de passagem, Centro de Referência de Assistência Social (CRAS), Centro de Referência Especializado de Assistência Social (CREAS), são realizados dentro da Rede Social da SEDEST.

A equipe do NUASO é formada por dezesseis educadores sociais e oito agentes sociais, que operam através da perspectiva da educação social de rua ${ }^{19}$. A entrevistada entende que o quadro de funcionários ainda é pequeno, mas ressalta que novas pessoas estão sendo contratadas. Cabe esclarecer a diferença entre as duas categorias de profissionais citadas anteriormente: o educador social possui nível superior e é licenciado. É ele quem faz os relatórios, os pareceres, e os encaminhamentos. Além disso, esse profissional é o responsável pela intervenção, pela abordagem, pelo processo de convencimento e de criação de vínculo com a população de rua. O agente social possui nível médio, e é quem oferece o suporte para o trabalho do educador.

O Núcleo atua de duas maneiras:

1) Abordagem sistemática: realizada em lugares com maior foco /concentração de população de rua. A Rodoviária do Plano Piloto é um dos espaços onde o NUASO atua com freqüência.

2) Averiguação de denúncias: a partir da Central SOS Cidadão (0800-6471407), são recebidas denúncias referentes a pessoas em situação de risco, como por exemplo, população de rua, pessoas desaparecidas, exploração sexual infantil. Os casos relacionados à população de rua são encaminhados ao NUASO.

\footnotetext{
${ }^{17}$ Procedimento no qual, os profissionais tentam estabelecer contato com a população de rua, procurando entender por que os indivíduos estão nesta situação, e quais mecanismos podem ser utilizados para propiciar melhoras nas condições de vida de tais sujeitos.

${ }^{18}$ Relação de confiança entre educador, agentes sociais, e a população de rua. Quando é estabelecida a confiança entre as partes, o trabalho de colher informações relacionadas à situação de vulnerabilidade dos indivíduos, e a aceitação dos serviços da SEDEST pelos mesmos, se torna mais fácil.

${ }^{19}$ Posteriormente à abordagem e à criação de vínculo com a população de rua, inicia-se o processo de educação social de rua. Por este, entende-se, a tentativa de inserção do indivíduo numa perspectiva de melhoria de vida, na qual, procura-se atender às demandas dos sujeitos, por meio da Rede Social da SEDEST.
} 
As abordagens proporcionam os encaminhamentos para diferentes instituições ou políticas, de acordo com as necessidades existentes. Depois de encaminhadas, o retorno sobre como estão essas pessoas é obtido apenas se houver alguma procura por essas informações por parte dos funcionários, o que dificilmente acontece. Outra maneira é através das abordagens, quando os profissionais encontram novamente os indivíduos na rua.

A entrevistada deixou claro que, durante as abordagens, as pessoas não são obrigadas a sair da rua, mas são orientadas sobre regras de convivência que precisam ser cumpridas. Todo esse processo de orientação é considerado lento, visto que grande parte da população atendida já possui vínculo com a rua. Acrescentou também que a equipe do Núcleo informa o indivíduo sobre seus direitos e a localização do Núcleo, para que, em caso de necessidade, haja fácil acesso aos educadores.

Ainda de acordo com a entrevistada, existem dificuldades relacionadas à abordagem. Em vista de todas as violações já sofridas e pela descrença em qualquer acolhimento governamental, muitas pessoas se recusam a receber o atendimento. Entretanto, foi informado que os encaminhamentos estão crescendo, mais pessoas estão participando da rede conveniada e a passagem de volta para a cidade natal tem sido mais usada. Neste último caso, o acompanhamento não é realizado.

Após a abordagem, quando há a comprovação de que uma pessoa/família atende os critérios de elegibilidade para receber algum tipo de benefício, estas são encaminhadas para o CRAS/CREAS. Quando a pessoa reside fora do DF, a situação é mais complicada, pois o indivíduo tem que ser assistido pela rede social da sua região, fator que por si só, prejudica uma articulação eficiente.

Segundo a entrevistada, muitos moradores de rua recebem o Benefício de Prestação Continuada (BPC) ${ }^{20}$, aposentadoria, e têm casa própria no entorno, mas como a renda não é suficiente, vão para as ruas com o objetivo de aumentar o orçamento, já que o dinheiro recebido através da esmola é superior ao obtido pelas fontes citadas. Uma das maiores demandas recebidas pela Secretaria é o pedido de serviços da Companhia de Desenvolvimento Habitacional do Distrito Federal - CODHAB/DF,

\footnotetext{
${ }^{20}$ O BPC é um benefício da Assistência Social, no valor de um salário mínimo, pago a idosos com mais de 65 anos, e a pessoas com deficiência incapacitante para a vida independente e para o trabalho. Ressalta-se que para ter acesso ao benefício, em ambos os casos (pessoas com deficiência e idosos) a família deve possuir a renda per capita inferior a 1/4 do salário mínimo.
} 
referentes à doação ou venda de lotes. Contudo, de acordo com a opinião da entrevistada, este serviço deve ser analisado com mais cautela já que muitas pessoas que vivem nas ruas do DF recebem seus lotes, vendem, e posteriormente requerem outro.

Tendo em vista que, após a abordagem da equipe do NUASO, grande parte da população de rua é encaminhada para o ALBERCON ${ }^{21}$, foi questionado se este pode ser considerado um bom local para acolher esses indivíduos. A entrevistada explicou que o albergue precisa de melhorias, mas que apresenta vantagens em relação à vida na rua, como por exemplo, acompanhamento de assistente social e de psicólogo, direito a alimentação, ao banho, entre outros. Disse ainda que um ponto fraco da instituição é a sua localização, pois quem trabalha no Plano Piloto tem que pagar caras passagens diariamente.

Acrescentou que o vínculo com a rua dificulta o encaminhamento para albergue, e que neste, todo o trabalho de acolhimento e encaminhamento para a Rede Social é facilitado. A entrevistada expôs que o GDF pretende, de acordo com a Resolução 109 do Conselho Nacional de Assistência Social (CNAS), implementar uma forma de acolhimento diário, no formato de um CREAS $^{22}$ especializado para atendimento da população de rua. Este local proporcionará uma qualidade de vida maior para os indivíduos que permanecem a maior parte de seu tempo nas ruas, visto que os mesmos terão acesso a oficinas, alimentação, banho, local para guardar seus pertences, descansar, entre outros. Além disso, a idéia é que esse CREAS seja implementado mais perto do Plano Piloto.

A entrevistada afirmou que hoje a principal campanha em Brasília é contra as doações e esmolas, pois, em sua opinião, estas práticas estimulam a permanência das pessoas na rua. De acordo com ela, a doação vem seguida da drogadição, e aqui no DF não há uma casa de desintoxicação eficaz a longo prazo, fato este que prejudica o acompanhamento necessário dos usuários e o auxílio às respectivas famílias.

\footnotetext{
${ }^{21}$ O Albergue Conviver (ALBERCON) é considerado uma unidade de atendimento a Serviços de Proteção Especial de Alta Complexidade ${ }^{21}$. A instituição, que é vinculada a SEDEST, tem como finalidade propiciar a (re)inserção de indivíduos em situação de vulnerabilidade à sociedade, através da fortificação dos vínculos rompidos, sejam estes familiares ou comunitários. Cabe destacar que o albergue encontra-se localizado próximo a cidade de Águas Claras - DF.

${ }^{22}$ A criação desse CREAS segue determinação, princípios e objetivos da Resolução 109 do CNAS, que define a Tipificação Nacional dos Serviços Socioassistenciais.
} 
A relação entre o Núcleo e a população de rua também é complicada. Nem sempre a equipe é bem recebida. Fatores como a idade dos usuários, o local onde habitam e se já sofreram muitas remoções são decisivos para facilitar ou dificultar o contato entre o governo e a população de rua. É mais freqüente não ser bem recebido por pessoas em situação de drogadição e por adolescentes que estão na rua totalmente desprotegidos pelo Estado. É comum também as pessoas confundirem o trabalho do NUASO com o trabalho realizado pela SUDESA.

Contudo, cabe esclarecer que o NUASO não acompanha as atividades de erradicação de invasões. Dentro da SEDEST, o Núcleo responsável por este trabalho é o NUCPS. Segundo a entrevistada, quando a SEDEST está presente nas remoções, a atuação dos outros organismos é diferente: existe um risco menor de violência e as ações são realizadas com mais cautela. Entretanto, quando há necessidade de outras áreas intervirem nos atendimentos, o NUASO entra em contato com as mesmas. Por exemplo, quando os moradores estão alcoolizados, com vestígios de drogadição, a Secretaria de Saúde é acionada pelo Núcleo, para que o atendimento seja feito com todo o aparato social necessário.

A entrevistada considera que a estrutura do Núcleo vem melhorando, mas é fundamental que o número de educadores e agentes sociais seja maior. Além disso, é importante que haja melhoria na Rede Social, construção de melhores Casas para atendimento, e capacitações de mais profissionais. Esses pontos contribuirão para que o trabalho do NUASO seja mais eficaz. Cabe ressaltar que a SEDEST está passando por uma reestruturação inédita: somente agora, depois de 20 anos sem concursos, é que houve uma seleção para contratação de novos profissionais.

Tendo em vista que a sistematização, articulação e coordenação de ações de assistência social, acompanhamento e avaliação dessas ações, são algumas das competências da SEDEST, espera-se que essas articulações sejam executadas de maneira eficaz e que tragam um retorno para a Secretaria. A esse respeito, a entrevistada disse que há uma articulação entre os Núcleos da SEDEST, e que toda sexta-feira os profissionais se reúnem no Núcleo de Ação Integrada - NAI, para a definição de estratégias de atuação e nivelamento de informações. 
Entretanto, para que as medidas do NUASO sejam mais efetivas, faz-se necessária uma melhoria no trabalho conjunto entre os próprios Núcleos da SEDEST. A Política Nacional de Assistência Social (PNAS) ajuda a compreender de que forma isto pode ser feito. Em sua opinião, a mídia também precisa auxiliar com campanhas contra a esmola e doações. A entrevistada acha que a Secretaria tem muito no que avançar e reconhece a resistência das entidades em atender a população de rua, seja na área da saúde quando nega um atendimento, seja quando os serviços assistenciais não chegam a essa população:

É uma população invisível, e a sociedade quer que seja invisível. Quando se tornam visíveis se tornam um incômodo, a sociedade indiretamente quer uma higienização da cidade. Temos a obrigação de dar cidadania à população de rua.

\section{NUCPS}

"No momento da ação os indivíduos se sentem extremamente violados, humilhados". (fala da assistente social do NUCPS)

O Núcleo de Proteção em Situação de Calamidades Públicas e de Emergências, anteriormente conhecido como Núcleo de Contingências, existe há aproximadamente um ano e meio, mas somente desde outubro de 2009 possui o atual nome. Para a obtenção dos dados necessários à pesquisa, realizou-se entrevista com a assistente social da instituição.

O NUCPS possui uma equipe formada por agentes sociais, sete assistentes sociais e três psicólogos. Os primeiros são os responsáveis pela coleta das informações durante as remoções. Os assistentes sociais, em virtude das diversas atividades que desempenham - elaboração de relatórios, pedidos, encaminhamentos, etc. - não participam de todas as ações.

O papel do NUCPS é de acolhimento e encaminhamento de pessoas em situações de emergência durante a ação - o fato de ser retirado do local onde mora é considerado uma situação de risco. Em remoções maiores, como a que está ocorrendo atualmente no $\operatorname{Varjão}^{23}$, há um trabalho preventivo, com encaminhamentos e orientações anteriores à ação de retirada. Não existe vínculo direto entre a instituição e o indivíduo. Entretanto, como grande parte das pessoas que a equipe encontra nas

\footnotetext{
${ }^{23}$ Devido à ocupação irregular da área de preservação ambiental pertencente ao Parque Ecológico da Vila Varjão, cerca de 127 famílias estão sendo transferidas para a cidade do Itapoã.
} 
ocupações são as mesmas, acaba-se gerando um vínculo indireto entre esta população e os profissionais do Núcleo.

As remoções, que ocorrem pelo menos uma vez por semana, são organizadas pela SUDESA a partir do pedido do Governador ou de denúncias da sociedade civil. O pedido para a solicitação das ações chega via fax. Apesar de o Núcleo só participar de remoções para as quais foi escalado, a entrevistada afirmou que quando há população de rua no momento das remoções, a equipe do NUCPS está presente. Cada retirada envolve parcerias que dependem das demandas das ações. Exemplos: Serviço de Limpeza Urbana do Distrito Federal (SLU), Polícia Militar do Distrito Federal (PMDF), Companhia de Saneamento Ambiental do Distrito Federal (CAESB), Companhia Imobiliária de Brasília (TERRACAP), SEDEST, SUDESA, entre outros.

Cabe destacar, que cada órgão participa de maneira independente nas ações. Quando estas duram mais tempo, o contato entre as equipes é maior em virtude da necessidade da realização de reuniões. Mesmo assim, os papéis de cada órgão devem permanecer claros: o papel da SUDESA é a erradicação. O do Núcleo é o acolhimento e a oferta de serviços da Rede Social da SEDEST. Frente a isso, durante as ações, o Núcleo tenta não demonstrar muito vínculo com a SUDESA.

No NUPCS também funciona o serviço de Plantão Social, que, respaldado pela PNAS, objetiva o atendimento

[...] às famílias e indivíduos com seus direitos violados, mas cujos vínculos familiar e comunitário não foram rompidos. Neste sentido, requerem maior estruturação técnicooperacional e atenção especializada e mais individualizada, e, ou, de acompanhamento sistemático e monitorado. (PNAS, pag.22, 2009)

Ressalta-se que este serviço é oferecido 24 horas, inclusive aos finais de semana e feriados.

Como os serviços oferecidos pelo NUPCS não possuem ligação direta com o NUASO, a entrevistada entende que por mais que haja uma relação de proximidade, devido, por exemplo, aos encaminhamentos para a Rede Social da SEDEST e às reuniões semanais entre as equipes da Secretaria de Desenvolvimento, não há uma efetiva articulação entre os Núcleos citados. Com relação à SUDESA, acredita que o trabalho tem se estreitado dentro do limite possível, pois, como já foi dito, cada órgão tem um papel definido. 
O trabalho realizado pelo NUCPS, segundo a entrevistada, é considerado eficaz no momento em que a equipe consegue retirar o indivíduo da ocupação irregular. No caso dos indivíduos que realmente moram em acampamentos, o trabalho é maior. Isto porque eles precisam de moradia, auxílios, e demais encaminhamentos. Outro ponto complicador é o trato de indivíduos que possuem casa fora do Plano Piloto: estes retornam para a ocupação no intuito de receber doações, ou por possuírem vínculo com a rua. A entrevistada reforça que a cultura de doações, principalmente em época de festas, é um problema.

No Plano Piloto as ocupações são compostas, em sua maioria, por migrantes, diferentemente das ocupações do entorno, que apresentam moradores do próprio Distrito Federal. De acordo com a entrevistada, a esperança que a população de rua tem em ganhar um lote, visto que esta foi à política do Governo durante muitos anos, está presente em todas as ocupações.

No que diz respeito às dificuldades enfrentadas pelo Núcleo, foi informado que o trabalho é realizado em uma Secretaria precária em recursos, em material, em visibilidade, e que, com isso, é difícil obter mais sucessos. Além disso, há dificuldade com os usuários que são resistentes a sair das ruas, por ser uma ação conjunta com órgãos "que estão ali para, de certa forma, feri-los", como é o caso da SUDESA. "No momento da ação os indivíduos se sentem extremamente violados, humilhados e, muitas vezes, a dificuldade está em chegar até essa pessoa."

O Núcleo participa das ações para tentar coibir a prática de violência durante as remoções, tanto a violência institucional, quanto à violência proveniente da população de rua. Segundo ela, o uso da força existe, admitindo-se ou não, pois há o desacato, prisão em flagrante, e não há como interferir quando a violência sai da área da assistência e vai para a área policial. Contudo, afirma que a violência feita de maneira desproporcional ou até mesmo ilegal, nunca foi presenciada, o que não quer dizer que não exista. Explicou ainda, que toda ação realizada gera um relatório, e isso pode ser um fator que iniba a violência. A participação do Núcleo na força tarefa serve para garantir o direito dos usuários. A SUDESA tem o direito de efetuar as remoções, mas os indivíduos também possuem direitos que precisam ser respeitados. 


\section{ALBERCON}

“Eu amo os albergados". (fala da coordenadora do albergue)

O Albergue Conviver (ALBERCON) é considerado uma unidade de atendimento a Serviços de Proteção Especial de Alta Complexidade ${ }^{24}$. A instituição, que é vinculada a SEDEST, tem como finalidade propiciar a (re)inserção de indivíduos em situação de vulnerabilidade à sociedade, através da fortificação dos vínculos rompidos, sejam estes familiares ou comunitários. Cabe destacar que o albergue encontra-se localizado próximo a cidade de Águas Claras - DF.

A coordenadora do ALBERCON informou estar no cargo há três anos, e explicou que o trabalho no albergue abrange duas frentes: uma macro - referente à articulação da Rede Social, que engloba todas as parcerias da instituição na prestação dos serviços aos usuários (saúde, passe livre, políticas públicas); e outra micro, que está relacionada à própria unidade e estrutura da instituição.

Os serviços do albergue estão disponíveis para migrantes, população de rua, moradores de rua ${ }^{25}$, famílias com direitos violados, e pessoas com os vínculos familiares e/ou sociais rompidos. Pode-se dizer que a maior parte dos usuários do ALBERCON é de migrantes que vieram à Capital em busca de melhores condições de vida, contudo, ao chegarem à cidade se depararam com dificuldades de emprego, transporte, moradia, e trabalho.

O trabalho realizado no ALBERCON conta com um quadro de funcionários composto por agentes, psicólogos e assistentes sociais. Segundo a coordenadora, o Albergue tem conseguido produzir um atendimento humanizado, no qual os usuários são ouvidos, respeitados, e encaminhados para os serviços necessários. Afirmou também que serviços como doação de passe de ônibus, emissão de carteira de identidade e outros documentos, são fornecidos com rapidez e eficiência, e isso pode ser

\footnotetext{
24 “Os serviços de proteção social especial de alta complexidade são aqueles que garantem proteção integral - moradia, alimentação, higienização e trabalho protegido para famílias e indivíduos que se encontram sem referência e, ou, em situação de ameaça, necessitando ser retirados de seu núcleo familiar e, ou, comunitário" (PNAS, 2004, pag. 22).

${ }^{25}$ A coordenadora do albergue faz distinção entre os termos "população de rua" e "moradores de rua". A primeira categoria se refere a pessoas que passam a maior parte do tempo na rua, mas que possuem residência; os moradores de rua seriam as pessoas que efetivamente vivem nas ruas.
} 
considerado até mesmo como um problema, pois já ocorreram situações nas quais muitas pessoas procuraram o albergue apenas para terem acesso a esses serviços.

Outros serviços oferecidos são: o acolhimento, que segundo a entrevistada é realizado em 100\% dos casos; os encaminhamentos - para a área da saúde, políticas públicas, política de habitação; e o acompanhamento ${ }^{26}$.

De acordo com a diretora, são realizadas atividades/oficinas de trabalho em grupo e/ou individual na instituição. Além disso, são oferecidas quatro refeições diárias aos abrigados. A comida é fornecida por uma empresa terceirizada. Ainda segundo a entrevistada, a alimentação é diversificada, é permitido repetir, e quando os albergados não gostam de algum prato, essa informação é repassada à empresa, para que o mesmo não volte a ser servido.

A violência dentro do albergue é freqüentemente citada pela população de rua de Brasília como um dos principais pontos que os desestimula a procurar este serviço de acolhimento. Contudo, a entrevistada negou que ocorra qualquer tipo de abuso de autoridade e explicou que considerando a quantidade de pessoas atendidas, o número de conflitos entre os abrigados é pequeno, ínfimo. Ressalta-se que a capacidade do albergue é de 520 pessoas, e que atualmente cerca de 450 indivíduos, entre homens e mulheres, encontram-se abrigados.

A diretora ressaltou que há um projeto de descentralização da instituição, em que serão construídos quatro albergues, cada um para uma determinada demanda (pessoas com deficiência, mulheres, entre outros). A distribuição será feita em quatro pontos localizados próximos às saídas de Brasília, e o atual será desativado. A implementação desse projeto propiciará um melhor atendimento aos indivíduos que necessitam dos serviços do ALBERCON.

Partindo do pressuposto de que a inserção dos albergados na sociedade é estimulada através da fortificação dos vínculos familiares e sociais rompidos, o retorno à cidade de origem é a política mais incentivada pela instituição. Contudo, a diretora afirmou que é complicado manter o acompanhamento dos indivíduos que retornam às

\footnotetext{
${ }^{26}$ Segundo a diretora entrevistada, o acompanhamento se dá quando agentes da instituição acompanham os usuários aos serviços de encaminhamento da Rede Social da SEDEST.
} 
suas cidades. De qualquer forma, os mesmos são orientados a procurar o CREAS e o CRAS de sua região.

A entrevistada acredita que o nível de satisfação dos albergados é bom e o tratamento recebido compensaria o problema da estrutura física, ponto que reconhece que precisa melhorar, visto que o albergue nunca passou por uma reforma desde sua inauguração, há 19 anos. Entretanto afirmou que o fato de muitos indivíduos preferirem permanecer na rua, em vez de ir para o albergue, se deve ao leque de possibilidades que a rua proporciona, como vícios, prostituição, boa alimentação, grande quantidade de dinheiro arrecadada diariamente (cerca de oitenta reais), e falta de "regras". A rua se torna mais atrativa do que o albergue, já que neste local não é permitido entrar com armas, drogas e existem regras e horários a serem cumpridos.

Acrescentou que a instituição não deve ser analisada como um local ideal, mas que, dentro do possível, atende as demandas de alimentação, higiene, dormitórios, realiza atividades (oficinas) de orientação e acolhimento, proporcionando uma qualidade de vida superior a de quem está na rua.

\section{ALBERGADOS}

“Os funcionários se acham 'Deus', inclusive a coordenadora”. (fala do entrevistado)

Tendo em vista a impossibilidade de aplicar entrevistas dentro do Albergue Conviver - já que não se obteve autorização da diretoria -, foi necessário ir ao comércio mais próximo da instituição para que esta etapa do trabalho de campo pudesse ser realizada. Sendo assim, três pessoas foram entrevistadas. As perguntas abordaram questões referentes à vida pregressa dos entrevistados e à permanência dos mesmos no albergue.

Os três participantes vieram do Nordeste com o intuito de conseguir melhores condições de vida na Capital. Dois foram orientados para irem ao ALBERCON quando ainda estavam na Rodoviária do Plano Piloto, mas afirmaram que nenhum outro tipo de encaminhamento foi realizado. Um destes ainda relatou que só foi para o albergue porque tinha a "ficha limpa", caso contrário teria sido mandado direto para a prisão. $\mathrm{O}$ outro entrevistado relatou ter recebido indicações de terceiros a respeito do albergue. 
Todos optaram por procurar acolhimento no Albergue, mas têm uma relação diferente com esta instituição e com a cidade: o primeiro entrevistado disse estar a aproximadamente um ano e três meses na Capital, e no albergue há seis meses. Acrescentou não ter morado na rua. Outra pessoa relatou estar em Brasília desde o ano de 2003, e que há dois anos vive na instituição. Disse que por motivos de perseguição só entra no albergue após a troca de plantão para pernoitar. O último entrevistado contou que vive em Brasília há mais de doze anos, e que está há bastante tempo no albergue, mas afirmou já ter residido nos cerrados do DF.

Conforme dito anteriormente, os entrevistados esperam alcançar melhores condições de vida na Capital e, para isso, ambicionam empregos formais. Os três têm profissões: um afirmou ser gráfico, outro auxiliar de montagem, e o último, auxiliar de faxina. Só este último possuía emprego fixo no período em que a entrevista foi realizada. Os outros dois fazem bicos eventualmente. Apesar do desemprego ou da inserção precarizada em um trabalho, só um entrevistado afirmou participar das atividades de orientação e acolhimento prestadas na instituição e já descritas neste capítulo. Os outros disseram não ter conhecimento dessas atividades.

Além de não se sentirem verdadeiramente acolhidos no albergue, devido à falta de estímulo para participação nas atividades e serviços oferecidos neste local, todos os entrevistados afirmaram sentirem-se inseguros na instituição. Os três passaram por situações de violência e/ou intimidação provenientes dos funcionários. Entretanto, uma das pessoas relatou que mesmo com a violência presente no albergue, se sente mais segura quando compara à época em que residiu nas invasões.

Esta entrevistada contou que, durante sua estadia no ALBERCON, teve seus filhos menores levados pelo Conselho Tutelar. Disse que na instituição existem outras crianças e que não entende o que aconteceu. Afirmou ainda, que além de não receber o passe de ônibus para visitar o marido na prisão e para ver os filhos no abrigo, tem duas filhas que não conseguem ser matriculadas na escola próxima ao albergue. Cabe ressaltar que as filhas são adolescentes e ainda não foram alfabetizadas.

Mesmo perante essas dificuldades, todos afirmam com veemência que preferem ficar em Brasília a voltar para suas cidades, pois, de outra forma, estariam em condições 
ainda piores. Um dos entrevistados disse ter esperanças de conseguir um lote, e que a instituição está auxiliando-o nesse sentido.

De acordo com os entrevistados, as maiores reclamações referentes ao albergue são relativas à violência que existe dentro da instituição e à alimentação - afirmam que a comida servida é "azeda". Negam que os serviços citados pela diretora, como o passe de ônibus, direito a telefonemas familiares, encaminhamentos para saúde, entre outros, sejam prestados com eficiência. Além disso, outro ponto negativo no ALBERCON é a sua localização: longe do Plano Piloto, local onde a maioria desses albergados trabalha.

\section{POPULAÇÃO DE RUA DE BRASÍLIA}

“Às vezes o Governo quer levar a gente pra um lugar pior do que a rua, como o Albergue". (fala do entrevistado)

As entrevistas com a população de rua de Brasília visaram o esclarecimento de questões como a naturalidade desses indivíduos, o tempo no qual os mesmos vivem nas ruas, o que fazem para sobreviver, se já passaram pela experiência de serem removidos do local onde residem e se tiveram algum tipo de assistência posterior às retiradas. Cabe ressaltar que, por viverem em acampamentos com pessoas que possuem trajetórias de vida semelhantes, pode-se considerar que os dados colhidos nesta pequena amostra, representam um número maior de indivíduos.

Os participantes da pesquisa residem na Capital em um intervalo de tempo que varia entre oito e trinta anos, sendo o mesmo intervalo de tempo apontado para os anos em que vivem nos acampamentos irregulares. De todos os entrevistados, apenas um é natural do Estado de Goiás, os outros três são originários das regiões Nordeste e Sudeste.

A reciclagem de materiais é o trabalho mais comum entre a população de rua pois, como já foi explicado, o lixo da Capital é um atrativo para os indivíduos que se encontram em total desproteção do Estado. Entretanto, um senhor relatou que por não ter mais condições de trabalhar como catador passou a vigiar carros em uma comercial da Asa Norte. Próximo à CAESB também foi identificado outro tipo de atividade, a criação e venda de Boró $^{27}$. Nesse caso, a senhora entrevistada afirmou vender as larvas

\footnotetext{
${ }^{27}$ Larva que cresce a partir de restos de alimentos em estado de putrefação.
} 
para pescadores, disse ainda, que a renda obtida nessa atividade é maior do que a venda de material reciclável.

Os entrevistados afirmaram que são retirados de suas moradias sem qualquer aviso-prévio do Governo do DF. Essas remoções, por sua vez, se tornaram tão recorrentes que podem chegar a uma incrível frequiência de três vezes em uma única semana, fato este que levou a população de rua de Brasília a criar estratégias para fazer frente às ações da SUDESA: escondem seus pertences no cerrado para evitarem um prejuízo maior caso as retiradas ocorram quando o acampamento estiver vazio.

Uma reclamação comum dos catadores é sobre a apreensão do material reciclável - guardado nos acampamentos -, como também, em relação ao recolhimento dos alimentos e pertences pela equipe da SUDESA. Essas apreensões são interpretadas pelos entrevistados como algo desnecessário e extremamente prejudicial e afirmam que se sentem desrespeitados e com seus direitos feridos. O uso de violência - psicológica, ou física - durante as remoções, foi citada por todos os participantes, que relataram não ter a quem recorrer nessas situações.

Além do sentimento de impotência frente à violência proveniente do Governo, os entrevistados se sentem abandonados pelo Estado. Este sentimento fica claro quando discorrem sobre os benefícios oferecidos pela SEDEST, tais como: o auxílio aluguel taxa de no máximo $\mathrm{R} \$ 330,00$ (trezentos e trinta reais) paga ao indivíduo por um período de até três meses -; acolhimento no albergue; e a oferta de passagem para fora do DF. Destas ofertas, apenas o convite ao acolhimento no ALBERCON foi feito para todos os entrevistados. Contudo, é unânime entre eles a preferência pela permanência na rua: mesmo tendo acesso à comida e a um local para dormir, todos acham o ALBERCON mais perigoso do que a rua, como pode ser observado pela afirmação de um deles reproduzida abaixo:

Nunca fui pra lá, mas conheço. Já me alimentei e tudo mais, mas ficar lá não, é muito ruim, é melhor ficar na rua. Se o Governo me falasse pra escolher entre morar aqui ou ficar lá, escolheria aqui (a rua).

Três dos quatro participantes disseram não ter vontade de voltar para a cidade de origem, pois, de acordo com os mesmos, as condições de vida oferecidas na Capital ainda são melhores. 
[...] se eu voltar pra lá eu vou ter que virar ou traficante, ou matador de aluguel, ou ladrão. Eu não tenho estudo, nem recurso de sobrevivência, e no Estado da Bahia só vive bem quem tem estudo e um bom trabalho. Se voltar a única forma de sobreviver é uma dessas três maneiras, e isso tudo é fim de carreira.

É importante ressaltar que um dos entrevistados afirmou ter um barraco alugado em Brasilinha - apelido da cidade Planaltina de Goiás. Entretanto, o mesmo informou que como seu "ganha pão" é no Plano Piloto, só vai para casa em alguns finais de semana, visto que a passagem é muito cara.

Dificuldades relacionadas à assistência na área da saúde também foram citadas, como: por exemplo, um senhor que está há meses esperando a assinatura de um cardiologista para conseguir o BPC, mas toda vez ocorre um imprevisto com o médico, fato que posterga os encaminhamentos para o recebimento do auxílio. Outros casos relacionados à indiferença, frutos de preconceitos contra a população de rua no momento de atendimentos médicos, também foram mencionados.

Cabe acrescentar que, a respeito da orientação e acolhimento que deveriam estar sendo feitos pela SEDEST, apenas dois entrevistados disseram ter tido breve contato com um assistente social, contudo, não foram devidamente esclarecidos sobre benefícios e programas a que tinham direito.

Tendo em vista o que foi apresentado, percebe-se que as instituições responsáveis pelo atendimento às demandas da população de rua do DF, principalmente a SEDEST, não têm conseguido alcançar grande êxito em suas ações. As remoções da SUDESA precisam ser constantes, caso contrário, o número de acampamentos irregulares aumentará. No que se refere ao NUASO, NUCPS e ALBERCON, mesmo com o discurso de que melhorias estão sendo feitas, é notório o uso de medidas paliativas e até mesmo de práticas higienistas contra a população de rua.

Outro ponto que merece atenção é a falta de articulação entre tais instituições, fato que, além de prejudicar a (re)inserção destes indivíduos na sociedade, ainda contribui para a perpetuação da marginalização dos mesmos pela própria sociedade. Esses e outros pontos serão melhor aprofundados no capítulo a seguir. 


\section{CAPÍTULO IV}

\section{A relação entre a SUDESA e a SEDEST e suas implicações para a população de rua}

Após a descrição de como se deu o trabalho de campo, será feita uma análise teórica e crítica a respeito das informações colhidas. Para tanto, este capítulo será dividido em três pontos principais, expostos a seguir.

\section{O DESCONHECIMENTO DA REALIDADE DA POPULAÇÃO DE RUA}

Em primeiro lugar é importante destacar que durante a realização do trabalho de campo foi possível notar que, tanto a SEDEST, quanto a SUDESA, possuem uma visão limitada a respeito da realidade da população de rua do Plano Piloto. Para justificar tal afirmação, serão expostos alguns pontos observados no momento das entrevistas.

A partir das declarações do subsecretário da SUDESA, em que o mesmo afirma que o foco das ações são as retiradas, percebe-se certo descaso em relação ao indivíduo/cidadão que sofrerá a remoção. Apesar de compreender que existe uma necessidade em encontrar solução para a diminuição dos acampamentos irregulares, e que este é um processo demorado, tendo em vista que o Estado precisa encontrar uma maneira de assistir de melhor forma esta população, o entrevistado justifica que "enquanto isso não acontece, não há como deixar as invasões tomarem conta da cidade" (sic).

Tal afirmação deixa clara a falta de envolvimento da equipe da Subsecretaria de Defesa do Solo e da Água com as demandas dos indivíduos em questão, o que implica a visão de que os catadores de material reciclável não são, portanto, percebidos como indivíduos desprotegidos ou em estado de vulnerabilidade, mas, ao contrário, são tidos como problema que deve ser resolvido independente de ter sido sanado, ou compreendido o motivo pelo qual estas pessoas passam a viver nas condições já elencadas.

O subsecretário, ao aludir que o trabalho da Subsecretaria seria mais eficaz se houvesse algum tipo de penalidade legal para quem vive nos acampamentos irregulares, reforça novamente a idéia de que tais indivíduos não são enxergados como cidadãos de 
direitos, mas como violadores de direitos, a partir do momento em que ocupam um território que, segundo o Estado, "não lhe pertencem". Além disso, demonstra falta de capacitação e esclarecimento da equipe quanto às dificuldades enfrentadas por trabalhadores que necessitam sobreviver na rua para ter como prover suas famílias.

À Secretaria de Estado de Desenvolvimento Social e Transferência de Renda, fica destinada, como forma de continuação ao "atendimento" da SUDESA, a identificação das demandas da população de rua do Distrito Federal e o posterior encaminhamento para a Rede Social da SEDEST.

Entretanto, e apesar de a equipe ter um contato direto com a população de rua, seja no momento da abordagem, nos encaminhamentos, ou no acolhimento - fato que exige maior capacitação e orientação por parte dos funcionários, principalmente quando se compara os profissionais da SUDESA e da SEDEST -, notou-se que há ainda, a necessidade de maiores esclarecimentos a respeito da realidade enfrentada por esses indivíduos.

Nesse sentido, pode-se dizer que a partir das entrevistas realizadas nos Núcleos da SEDEST, foi verificado que as equipes, mesmo tendo maior percepção referente às condições e dificuldades enfrentadas pela população de rua, além da vontade de realizar o trabalho de maneira com que a situação dessa população seja superada, não é capaz de mudar uma realidade social, visto que os funcionários se encontram inseridos em um contexto no qual as ações são limitadas.

Ressalta-se que tais limitações são apresentadas principalmente por parte da instituição e do Governo, no sentido de se deparar com restrições quanto aos encaminhamentos, ou falhas na articulação da Rede Social da SEDEST, por exemplo. Além disso, cabe destacar o fato de a equipe ter muitas vezes, imbricada em suas concepções, a idéia de que a população de rua possui condições de superar a situação a qual estão inseridas a partir do trabalho realizado pela Secretaria. Contudo, sabe-se que devido ao histórico de vida desses sujeitos, exposto no capítulo II deste trabalho, as ações votadas a essa população não podem se restringir a medidas pontuais e paliavas, mas precisam abranger um caráter de continuidade e acompanhamento posterior aos encaminhamentos. 
A título de ilustração a respeito das exposições acima, incumbe relembrar a fala da entrevistada do NUASO, quando a mesma afirma que grande parte da população de rua possui residência própria, ou Benefício de Prestação Continuada, acrescentando, portanto, que os indivíduos que residem, ou passam boa parte do tempo nas ruas, além de possuírem um vínculo com a mesma, encontraram uma maneira mais "fácil" de complementar a renda familiar, visto que, ao pedirem esmola, acabam por vezes, recebendo uma quantia mais alta que alguns benefícios concedidos pelo Governo.

Essa visão de que é necessária uma "maior boa vontade" por parte da população de rua para sair de sua situação de vulnerabilidade, ao invés de focar na luta por melhorias nas políticas sociais, assim como também, na própria Rede Social da SEDEST, foi verificada também, durante as entrevistas realizadas no NUPCS e, principalmente, no ALBERCON.

Dentro do que foi exposto, é interessante deixar claro a dificuldade que as equipes profissionais da SUDESA e SEDEST apresentaram em compreender de maneira mais aprofundada e crítica a situação a que estão sujeitas as pessoas que vivem nas ruas do Plano Piloto. É fato que o trabalho realizado pela SEDEST pode ser considerado positivo quanto às suas tentativas de reinserção dessa população na sociedade. Entretanto, se faz necessário um trabalho capaz de superar a visão culpabilizadora desses indivíduos, no sentido de compreender que, na realidade, ao retroceder à história da formação da sociedade capitalista, o Estado é quem possui uma dívida para com a população de rua.

\section{DESARTICULAÇÃO ENTRE SUDESA e SEDEST}

Apesar do discurso apresentado em relação à articulação das equipes da SUDESA e SEDEST no desenvolvimento das ações para com a população de rua, foi observado que ambas, por possuírem funções e quadro de funcionários diferenciados, apresentam diferentes posições no que se refere à percepção da categoria população de rua. 
A partir da explicação apresentada no capítulo III, a respeito do que vem a ser a "Força Tarefa ${ }^{28}$ ", e retomando a idéia de que a SUDESA é responsável por organizar ações que têm como maior objetivo o cumprimento de uma ordem de remoção, enquanto a SEDEST deve realizar uma abordagem que vise à proteção dos indivíduos em vulnerabilidade, subentende-se que as equipes trabalham de forma articulada.

No entanto, a parceria ou articulação, entre a SUDESA e a SEDEST, partindo da análise das entrevistas dos profissionais e da própria população de rua, mostrou-se superficial, tendo em vista, que a chamada Força Tarefa, apesar de abranger ambas as equipes, é realizada de forma particular por cada órgão governamental, no qual cada parte, por ter um papel definido no momento da atuação, executa suas ações sem que haja efetivamente um trabalho em equipe. Ou seja, não há a execução de um trabalho interdisciplinar, mas sim, individualizado.

De acordo com uma das entrevistadas da Secretaria de Estado de Desenvolvimento Social e Transferência de Renda, antes de uma operação é decidido quem iniciará a abordagem da população: se será a equipe da SUDESA, ou da SEDEST. Entretanto, ela afirmou que há uma confusão por parte da população de rua, sobre a diferença na atuação das equipes. Disse ainda, que quando os funcionários do NUPCS $^{29}$ estão presentes nas ações de remoção, eles tentam não demonstrar muito vínculo com a SUDESA, pois, isso "prejudicaria" o trabalho do núcleo, visto a diferença de objetivos que cada equipe possui durante uma retirada.

Os próprios núcleos da SEDEST também possuem uma articulação precária. A fala das entrevistadas deixa claro tal ponto de vista, quando é afirmado que cada núcleo possui uma competência e que, após a realização dos procedimentos com a população de rua, não há retorno em relação aos resultados dos encaminhamentos. Ressalta-se, que a secretária da NUPCS afirmou que, a não ser em operações maiores, nas quais é realizado um trabalho preventivo, não há vínculo direto entre os indivíduos atendidos e os profissionais do núcleo, acrescentando que o trabalho de criação de vínculo é desenvolvido pelo NUASO.

\footnotetext{
${ }^{28}$ Espécie de colegiado em que vários órgãos do GDF são designados para atuar em uma demanda muito grande que, no caso da referida Secretaria, é a ocupação ilegal de terra.

${ }^{29}$ Núcleo que participa das operações com a SUDESA
} 
Sendo assim, subtende-se que os serviços de acolhimento dos núcleos citados, apesar de possuírem uma articulação mais estreita, se comparada com a relação entre SUDESA e SEDEST, deixam a desejar no quesito acompanhamento, visto que, além de não haver um retorno sobre os encaminhamentos e se os indivíduos foram efetivamente acolhidos, não foi constatado, nenhum tipo de instrumental que se aprofunde no atendimento da população de rua.

Nesse sentido, seria interessante que houvesse, por exemplo, um trabalho de estudo de caso a respeito dos indivíduos atendidos pela SEDEST, para que, assim, fosse possível entender de que forma o mesmo chegou à sua atual situação, e o que pode ser feito para melhorar a vida dessa população de maneira concreta. $\mathrm{O}$ fato de não haver um acompanhamento mais aprofundado, nem informações a respeito do histórico do indivíduo, demonstra que os atendimentos não deixam, portanto, de ser pontuais e paliativos.

Diante do exposto, é necessário abarcar também a visão da população de rua entrevistada, tomando como referência a percepção desses indivíduos sobre as ações de remoções, abordagem, acolhimento e encaminhamento.

Com exceção de dois entrevistados, foi constatada a falta de orientação pelas equipes de abordagem e acolhimento, quanto à participação da população de rua em programas e benefícios a que tinham direito, e da ausência de relatos a respeito do contato com assistentes sociais. Além disso, os participantes alegaram que durante as retiradas têm seu material de reciclagem apreendidos, juntamente com seus alimentos e pertences.

Em relação aos encaminhamentos realizados pela SEDEST, é importante enfatizar que os mesmos não condizem com as reais necessidades da população de rua. Cabe destacar, que as únicas formas de encaminhamento citadas pela população de rua durante o trabalho de campo foram:

a) ALBERCON: local em que os participantes da pesquisa se recusam a freqüentar, pois, segundo declarações, no albergue há mais perigo e violência do que na rua;

b) Auxílio aluguel: apenas um participante disse ter recebido. De acordo com o entrevistado, devido ao baixo valor do auxílio, a localidade do imóvel a ser 
alugado é um dos problemas para os indivíduos que trabalham na capital. A quantia oferecida pelo Governo não permite que indivíduo resida em local próximo ao Plano Piloto, o que por sua vez, dificulta algum tipo de melhoria para os assistidos, visto que, a distância do imóvel alocado se transforma em mais um problema de locomoção, tornando inviável o ir e vir desses trabalhadores todos os dias para suas casas, em virtude do preço das passagens. Assim, esses indivíduos se vêem inseridos novamente em sua situação anterior: a de moradores de rua.

Como já foi dito no capítulo anterior, os entrevistados afirmaram que as retiradas são recorrentes, chegando a acontecer várias vezes por semana, e que todas essas violações resultam em um sentimento de impotência frente às operações do Governo, pois, ao não receberem a devida atenção no momento das remoções, não são orientados sobre o que podem fazer para sair da situação em que se encontram, e, portanto, não sabem a quem recorrer para reaver seus materiais e reclamar seus direitos.

Após essa breve explanação, é possível notar que há uma incoerência na fala dos entrevistados, sejam estes, profissionais do Governo ou catadores de material reciclável. Tal fato evidencia o problema da desarticulação entre SUDESA e SEDEST, no sentido de que as informações obtidas, por meio das entrevistas nos acampamentos irregulares, não refletem a realidade vivenciada pela população de rua do Plano Piloto.

\section{POLÍTICAS DE ASSISTÊNCIA SOCIAL PARA A POPULAÇÃO DE RUA}

A criação e implementação de políticas sociais, não só para a população de rua, mas também, para outros indivíduos e grupos sociais, deve ser realizada a partir de estudos e articulações com o público alvo, para que, assim, as medidas tomadas alcancem de forma mais contundente as demandas e necessidades dos indivíduos em questão, sem criar estigmas e preconceitos aos assistidos.

De acordo com Pereira, as políticas de assistência social continuam - desde as leis dos pobres - priorizando os indivíduos que sejam originários do local onde serão assistidos, ou estejam por um período mínimo de tempo em tal localidade. Assim, temse reforçado "dois princípios que se fazem valer até hoje: o da residência e o da 
naturalidade como condição para o pobre ter direito à assistência social" (PEREIRA, 2000, pag. 65).

Tal fato pode ser constatado a partir das explanações realizadas na presente pesquisa, na qual ficou clara, principalmente, a política de retorno à cidade natal. A própria entrevistada do ALBERCON afirmou que é comum a utilização deste "serviço" no albergue; contudo, o mesmo não é eficiente, visto que é recorrente a volta dos indivíduos para Brasília.

Sendo assim, o auxílio aluguel, os encaminhamentos para albergues (sem contar para a área da saúde, que é muito precária), e a passagem de volta para a cidade de origem - políticas utilizadas na cidade de Brasília - mostram-se ineficientes, seja pela falta de estrutura das instituições de acolhimento, como no caso do ALBERCON, ou pela própria inviabilidade da política.

Se um indivíduo sai de sua cidade natal a procura de uma vida melhor, e ao chegar à nova cidade, apesar da precária condição em que se encontra, ainda prefere continuar em tal situação, não é difícil constatar que não é o fato de gostar/querer viver na rua, mas compreender que, embora esta não seja a condição ideal, para o indivíduo ainda é a sua melhor opção. Entretanto, ao permanecer nas ruas, esses indivíduos se tornam um transtorno, um incômodo que deve permanecer invisível aos olhos da cidade.

Compreende-se que as ações de remoções e encaminhamentos, geralmente não surtem efeitos positivos a nenhum dos lados, nem aos profissionais da SUDESA e SEDEST, nem à população, que continua em sua maioria desprotegida e desamparada pelo Estado. Portanto, as políticas sociais voltadas para a população de rua do DF, executadas em grande parte pela SEDEST, ao invés de promover o bem estar dessa população, e proporcionar, por conseqüência, "cidadania" a esses indivíduos, deixa a desejar no seu objetivo.

Cabe dizer que, ao não cumprir seu papel de protetor e garantidor de direitos, o Estado acaba por produzir um sentimento de culpabilização na população de rua, que é perpassado para a sociedade como um todo, e reproduzido diariamente, causando repulsa e indiferença a tais indivíduos. 
Assim, infere-se que a população de rua, ao chamar a atenção da sociedade de maneira negativa, contribui para que o Estado tome medidas pontuais e paliativas que, em vez de fornecerem melhorias de vida para esses indivíduos, auxilia na propagação da visão de que a assistência social possui caráter assistencialista que, ao não propiciar maior equidade entre os indivíduos, fica caracterizada como uma política que sustenta e reproduz a pobreza.

Para finalizar, destaca-se a importância de desenvolver políticas sociais voltadas à inclusão e proteção da população de rua na sociedade. Dentro desse contexto, e para fins de esclarecimento dos conceitos aludidos, cabe uma citação de SPOSATI ao distinguir proteção de inclusão:

Alguns responderão que proteção e inclusão são similares e que buscar proteção é estar incluído. Com certeza, no entendimento mais chão, inclusão significa ser parte de, ser aceito por. Inclusão é uma situação relativa e que, em grande parte, deriva de superação de estigmas e discriminações. A proteção social vai além da superação de estigmas e de apartações. A proteção à dignidade humana alcança mais situações de equidade (SPOSATI, 2009, pag.16)

A partir do que foi exposto, fica visível a precária articulação entre os organismos do Governo do Distrito Federal que lidam com pessoas de rua. Saúde, escola, alimentação, trabalho e moradia, são direitos básicos que qualquer ser humano deve ter acesso, e o Estado deve ser o garantidor dos mesmos.

O tipo de ação governamental voltada para a população de rua causa transtornos à sociedade em geral: ao Governo, por não ter eficácia em suas ações; à população, que enxerga esses indivíduos como preguiçosos, marginais, pessoas em situação de drogadição, alcoolistas, entre outros; e aos próprios desabrigados, que além de sofrerem todo tipo de preconceito e opressão, não possuem meios para sair da situação em que se encontram. Sendo assim, a importância de um maior empenho na geração e efetivação das políticas sociais juntamente com o acompanhamento de todas as partes envolvidas se faz necessária e urgente. 


\section{CONSIDERAÇÕES FINAIS}

Faz-se imprescindível, antes de tudo, pontuar a crescente descrença da população de forma geral, e em específico, da população de rua, na atuação do Estado. Esse é coisificado, visto como um "ente"; entretanto, sem eficácia e eficiência em suas estratégias, propostas e programas.

Ademais, o Estado se mostra exercendo um papel predominantemente repressivo, o que se exemplifica por meio de políticas coercitivas e higienistas aplicadas pelas Secretarias e Subsecretarias do DF, como, por exemplo, a SUDESA. Ou então, corroborando o ideário neoliberal de comprometimento e responsabilidade mínima pela população e sociedade, extraindo, dessa forma, o caráter universal e amplo das políticas sociais, em favor de políticas focalizadas, fragmentadas e assistencialistas, que se fazem por um caráter emergencial e imediatista, a exemplo da SEDEST.

É importante pontuar a percepção de que as políticas sociais voltadas para a população de rua do Distrito Federal apontam para uma inversão de foco: ao invés de visarem a emancipação desses indivíduos em situação de vulnerabilidade, através da proteção estatal, tirando-os das ruas, o que parece estar sento feito é justamente o contrário. A população é retirada das ruas para não causar incômodo à sociedade civil. Como exemplo do exposto, menciona-se os encaminhamentos para o ALBERCON, que além de não possuir estrutura física para receber esses indivíduos, ainda representa perigo aos mesmos.

Destaca-se então, que as hipóteses desta Pesquisa foram confirmadas a partir da compreensão, alcançada através do trabalho de campo, de que os organismos que executam as políticas sociais voltadas para a população de rua do Distrito Federal não possuem uma articulação eficaz. Tal fato é notável tendo em vista a constância nas remoções praticadas pela SUDESA, a precariedade no acolhimento e encaminhamento desses indivíduos pela SEDEST, assim como também a característica paliativa que tais ações apresentam. 


\section{REFERÊNCIAS BIBLIOGRÁFICAS}

ANTUNES, Ricardo. Crise Capitalista Contemporânea e as transformações no mundo do trabalho. IN: Capacitação em Serviço Social e Política Social. Módulo 01: Crise Capitalista contemporânea, questão social e serviço social. Brasília: CFESS, 1999.

BEHRING, E. R.; BOSCHETTI, I. Política social: fundamentos e história. 2 ed. São Paulo: Cortez, 2007. (Biblioteca básica de serviço social; v. 2).

BRASIL, Lei 8742/93 - Lei Orgânica da Assistência Social.

BRASIL, Constituição da República Federativa do Brasil. Atualização e índice de Paulo Roberto Moraes de Aguiar com a revisão de Angelina Almeida Silva. Brasília: Senado Federal.

ENGELS, Friedrich. A Situação da Classe Trabalhadora na Inglaterra. São Paulo: Boitempo, 2008.

HUBERMAN, Leo. História da riqueza do homem. $21^{\mathrm{a}}$ ed. Rio de Janeiro: Guanabara, 1986.

JUNIOR, Aécio. Evolução histórica da Previdência Social e os direitos fundamentais. Disponível em: 〈http://www1.jus.com.br/doutrina/texto.asp?id=6881>. Acesso em: 31 de maio de 2010.

MALTHUS, Thomas Robert. Princípios de economia política: e considerações sobre sua aplicação prática; Ensaio sobre a população. Apresentação de Ernane Galvêas. Traduções de Regis de Castro Abreu, Dinah de Abreu Azevedo e Antonio Alves Cury. São Paulo: Abril Cultural, 1983. (Os Economistas)

PEREIRA, Camila Potyara. Rua sem Saída: um estudo sobre a relação entre o Estado e a população de rua de Brasília. Brasília: Ícone Gráfica e Editora, 2009.

PEREIRA, Potyara A. P. A Assistência Social na perspectiva dos direitos: crítica aos padrões dominantes de proteção aos pobres no Brasil. Brasília: Thesaurus, 1996.

- Necessidades Humanas: subsídios à crítica dos mínimos sociais. São Paulo: Cortez, 2000.

SALES, Teresa. Raízes da desigualdade social na cultura política brasileira. In: Revista Brasileira de Ciências Sociais, n.25, ano 9, jun. 1994, p. 26-37.

SCHWARTZMAN, Simon. Vantagens e desvantagens das linhas de pobreza. Disponível em: < http://www.schwartzman.org.br/simon/linhas.htm> Acesso em: 30 de maio de 2010.

SILVA, Maria Lucia Lopes da. Mudanças recentes no mundo do trabalho e o fenômeno população em situação de rua no Brasil 1995-2005. 2006. 220 f. Dissertação (Mestrado em Política Social)-Universidade de Brasília, Brasília, 2006. 
SPOSATI, Aldaíza. Políticas Públicas em Debate, ciclo de seminários. In: Seminário de Política de Assistência Social: Novos Desafios. Fundap em 30 de junho de 2009.

TOCQUEVILLE, Alexis de. Ensaio sobre a Pobreza. Rio de Janeiro: UniverCidade, 2003 , p. 85.

VALLA, Victor Vicent. Globalização, a questão social e a nova pobreza. In: VALLA, Victor Vicent; STOTZ, Eduardo Navaro \& ALGEBAILE, Eveline Bertino. Para compreender a pobreza no Brasil. Rio de Janeiro: Contraponto: Escola Nacional de Saúde Pública, 2005.

VELOSO, Sainy C. B. A visibilidade dos sem-teto no Plano Piloto de Brasília. In: XIII Encontro de História Anpuh-Rio: Identidades, 2008, Rio de Janeiro. XIII Encontro de História Anpuh-Rio.

ZIMMERMANN, Clóvis; SILVA, Marina da Cruz. As experiências internacionais de renda mínima na redução da pobreza. Disponível em: < http://www.espacoacademico.com.br/082/82zimmermann.htm> Acesso em: 27 de maio de 2010. 


\section{Anexo 1 - Roteiro de Entrevistas}

\section{SUDESA}

\section{Entrevista 1}

1) Cargo:

2) Como são feitas as retiradas dos moradores de rua pela SUDESA? Existe alguma medida de proteção aos moradores antes/após as remoções?

3) É correto dizer que as ações da SUDESA visam somente à desocupação dos terrenos, e por isso, não há envolvimento social nessas ações?

4) Em que medida essas retiradas são eficazes:

a) Em relação ao não retorno dos ocupantes;

b) Em relação à realocação de famílias;

5) Qual o procedimento com as crianças?

6) Qual o seu ponto de vista em relação às denúncias de violência praticadas pela Polícia Militar contra a população de rua durante as retiradas?

7) Qual o gasto gerado com essas retiradas, sabendo que em muitas invasões, é só uma questão de tempo para que os ocupantes voltem a residir no mesmo lugar?

8) Há algo que possa ser feito para que as retiradas sejam definitivas?

9) Existe articulação da SUDESA com outras esferas do Governo? Como se dá essa articulação?

10) Na sua visão o que pode ser melhorado, ou que pode ter maior atenção nas ações de retirada da população de rua do Plano Piloto?

11) Se necessário, posso entrar em contato com você novamente?

\section{Entrevista 2}

1) Cargo

2) Como é a parceria da SUDESA com o Núcleo de Proteção em Situação de Calamidades Públicas e de Emergências? O Núcleo participa de quais retiradas?

3) O que mudou durante as ações da SUDESA com esta parceria?

4) Qual a importância dessa articulação?

5) Atualmente qual é a maior demanda do Plano Piloto nas retiradas:

a) Em relação à origem das pessoas?

b) Em relação às atividades que realizam? 
c) Em relação ao motivo que as fazem permanecer na rua?

6) Ano passado ocorreram diversas denúncias contra a violência utilizada durante as retiradas da SUDESA, inclusive denúncias contra funcionários da Subsecretaria.

a) O que você pode falar a esse respeito?

b) Por que esse tipo de violência ocorre?

7) O que pode ser feito para minimizar esses problemas?

8) Os funcionários da Subsecretaria recebem algum tipo de capacitação para lidar com a população de rua do DF? Com que frequiência?

9) Como a população de rua reage às constantes retiradas?

10) A efetivação e eficácia das retiradas ficam comprometidas com volta da população de rua às invasões, a partir disso, como a equipe lida com essa situação? Como a SUDESA age caso a população de rua reaja com violência?

11) Se necessário, posso entrar em contato com você novamente?

\section{SEDEST/NUASO}

1) Cargo;

2) Como é o trabalho realizado pela SEDEST com os moradores de rua do Distrito Federal?

3) O que a SEDEST entende por morador de rua, ou população de rua?

4) Existe alguma política de assistência aos moradores de rua? Quais?

5) Quais são as ações do Governo Arruda nessa área? Os resultados estão sendo positivos? Com o envolvimento do Governador no atual escândalo de corrupção, alguma ação da SEDEST perdeu força?

6) Como é a estrutura para a efetivação das ações?

7) Em que medida as ações da SEDEST atendem as demandas da população de rua?

8) Existe algum trabalho feito com as crianças?

9) Os moradores de rua têm ciência de que possuem meios de serem auxiliados pelo governo, ou isso não é conversado com eles quando os mesmos são abordados?

10) Como eles podem ter acesso aos benefícios?

11) O ALBERCON pode ser considerado um bom local para alocar a população de rua? Ele é capaz de suprir as necessidades mínimas desses indivíduos?

12) Tendo em vista que as competências da SEDEST são:

- Sistematização, articulação e coordenação de ações de assistência social e de segurança alimentar; Acompanhamento e avaliação das ações de assistência social e de segurança alimentar; Interação com demais órgãos para implementação das políticas e diretrizes sociais; 
Assegurar a destinação de recursos orçamentários e financeiros para a área social; Buscar incentivos para a área social; Incentivar a participação da sociedade civil e organismos nacionais e internacionais.

Como essas articulações são efetivadas, e qual o retorno que as mesmas trazem para a SEDEST?

13) Qual a relação entre a SEDEST e a SUDESA?

14) O que pode ser melhorado para que as medidas da SEDEST sejam mais eficazes?

15) Se necessário, posso entrar em contato com você novamente?

\section{SEDEST/NUCPS}

1) Cargo:

2) Há quanto tempo existe o núcleo? Em que localidades atua?

3) Como é realizado o trabalho do Núcleo? Qual o objetivo?

4) Como é a relação / articulação do Núcleo com a SUDESA? Existem outros parceiros?

5) Já presenciou casos de violência do pessoal da SUDESA contra a população de rua?

6) Quais os profissionais envolvidos nas retiradas? Existe capacitação?

7) Como é o procedimento com a população de rua durante as retiradas? Esta população é orientada, ou encaminhada para alguma política pública? Quais?

8) Como os profissionais do Núcleo são recebidos pela população de rua no momento das remoções?

9) Há algum trabalho realizado com a população de rua que não abandona o local onde vive, apesar das retiradas, fazendo com que estas sejam rotina no seu dia-dia?

10) Qual a maior demanda durante as remoções?

11) Existe acompanhamento da população de rua posteriormente às retiradas?

12) Existe articulação do Núcleo com o NUPOR? Como é essa relação?

13) Em que medida o trabalho realizado pelo Núcleo é eficaz?

14) Qual a maior dificuldade enfrentada pelo Núcleo, para que o trabalho tenha um retorno mais eficiente?

15) Acha deveria haver maior articulação entre a SEDEST e SUDESA? Como isso seria possível?

16) Caso necessário, posso entrar em contato com você novamente?

\section{ALBERCON}

1) Cargo 
2) Qual a sua função no ALBERCON?

3) Qual o objetivo do ALBERCON? Ele vem sendo alcançado? Em que medida?

4) Quem pode utilizar os serviços do Albergue? Qual é a maior demanda?

5) Como é o trabalho realizado no ALBERCON para a população de rua?

6) Qual o nível de satisfação dos usuários do albergue na sua concepção? Por quê?

7) O ALBERCON pode ser considerado um bom local para alocar a população de rua? Ele é capaz de suprir as necessidades mínimas desses indivíduos?

8) Existem casos de pessoas que prefiram ficar nas ruas em vez de permanecerem no ALBERCON? Por quê?

9) O Governo tem conhecimento dos problemas enfrentados pelo albergue? Que providências são/foram tomadas? O ALBERCON possui parcerias com outros órgãos, com ONGs?

10) O que pode ser melhorado no ALBERCON?

11) Se necessário, posso entrar em contato com você novamente?

\section{$\underline{\text { Albergados }}$}

1) Idade;

2) Profissão;

3) Nacionalidade; há quanto tempo está em Brasília? Veio para a cidade com qual intuito?

4) Como descobriu o ALBERCON?

5) Gosta do ALBERCON? Por quê?

6) Há quanto tempo reside no Albergue? Por quê?

7) Já morou na rua? Por quanto tempo?

8) Qual a diferença entre viver no Albergue, e viver na rua?

9) O que te fez vir para o ALBERCON?

10) O que faz quando não está aqui?

11) Que atividades o ALBERCON proporciona para você?

12) Você se sente seguro no Albergue? Por quê?

13) Qual a maior dificuldade enfrentada no Albergue?

14) O que você precisa para sair do Albergue?

15) O que pode ser melhorado no Albergue?

16) Recebe, ou já recebeu algum benefício do Governo? 
17) Se necessário, posso entrar em contato com você novamente?

\section{População de rua}

1) Idade:

2) Naturalidade:

3) Há quanto tempo reside:

a) Em Brasília?

b) No acampamento?

c) Na rua?

4) O que faz para sobreviver?

5) Já passou pela experiência de ser retirado do local onde reside? Quantas vezes?

6) Para onde foi encaminhado? Caso tenha retornado, por quê?

7) É É (ou já foi) assistido por alguma política do Governo? Qual?

8) Já teve contato com alguma assistente social?

9) Conhece alguém do Governo?

10) O que gostaria que fosse feito para melhorar sua situação?

11) Tem vontade de voltar para sua cidade? Se sim, o que é necessário para que isso aconteça?

12) Se necessário, posso entrar em contato com você novamente? 


\section{Anexo 2 - Termo de consentimento livre e esclarecido}

Você está sendo convidado(a) como voluntário(a) a participar da pesquisa: Análise dos organismos de execução e implementação das políticas sociais voltadas para população de rua de Brasília.

O objetivo desta pesquisa é analisar o grau de articulação e as consequiências da mesma, entre as Secretarias do Governo do DF que atuam em parceria na execução das políticas sociais voltadas aos moradores de rua do Plano Piloto.

O procedimento de coleta de dados ocorrerá através de entrevista semi-estruturada com moradores de rua de Brasília, pessoas ligadas as Secretarias do Governo do Distrito Federal SUDESA e SEDEST - , além da contínua análise de documentos e de bibliografias afins com o tema estudado.

Você será esclarecido(a) sobre a pesquisa em qualquer aspecto que desejar. Você é livre para recusar-se a participar, retirar seu consentimento ou interromper a participação a qualquer momento. A sua participação é voluntária e a recusa em participar não irá acarretar qualquer penalidade ou perda de benefícios.

A pesquisadora irá tratar a sua identidade com padrões profissionais de sigilo. Haverá retorno dos resultados, seja por meio de oficinas, ou emissão por e-mail, sendo que as informações coletadas permanecerão confidenciais. Seu nome ou o material que indique a sua participação não será liberado sem a sua permissão. Você não será identificado(a) em nenhuma publicação que possa resultar deste estudo.

A participação no estudo não acarretará custos para você e não será disponível nenhuma compensação financeira adicional.

$\mathrm{Eu}$, fui informada (o) dos objetivos da pesquisa acima de maneira clara e detalhada e esclareci minhas dúvidas. Sei que em qualquer momento poderei solicitar novas informações e motivar minha decisão se assim o desejar. Declaro que concordo em participar desse estudo. Recebi uma cópia deste termo de consentimento livre e esclarecido.

Em caso de dúvidas poderei chamar a estudante no telefone (61) 8184-4444.

Assinatura:

Telefone/ e-mail:

Data: 